\title{
AERIAL RADIOLOGICAL MEASURING SURVEY OF THE AREA SURROUNDING BIG ROCK POINT NUCLEAR PLANT, BIG ROCK POINT, MICHIGAN, 1968
}

by

M. D. Sevart

EG\&G, Inc., Las Vegas, Nevada

\begin{abstract}
This report was prepared as an account of work sponsored by the United States Government. Neither the United States nor the United States Atomic Energy Commission, nor any of their employees, nor any of their contractors, subcontractors, or theur employees, makes any warranty, express or implied, or assumes any legal liability or responsibility for the accuracy, completeness or usefulness of any information, apparatus, pleteness or usefulness of any information, apparatus, product or process disclosed, or represents
would not infringe privately owned rights.
\end{abstract}

This report is part of a series on the continuing activities of the Aerial Radiological Measuring System operated for the U.S. Atomic Energy Commission. The ARMS program is managed by the Division of Operational Safety and is a cooperative effort among various offices and divisions of the Commission. 


\section{DISCLAIMER}

This report was prepared as an account of work sponsored by an agency of the United States Government. Neither the United States Government nor any agency Thereof, nor any of their employees, makes any warranty, express or implied, or assumes any legal liability or responsibility for the accuracy, completeness, or usefulness of any information, apparatus, product, or process disclosed, or represents that its use would not infringe privately owned rights. Reference herein to any specific commercial product, process, or service by trade name, trademark, manufacturer, or otherwise does not necessarily constitute or imply its endorsement, recommendation, or favoring by the United States Government or any agency thereof. The views and opinions of authors expressed herein do not necessarily state or reflect those of the United States Government or any agency thereof. 


\section{DISCLAIMER}

Portions of this document may be illegible in electronic image products. Images are produced from the best available original document. 


\begin{abstract}
The Aerial Radiological Measuring System (ARMS), operated for the U. S. Atomic Energy Commission, was used to perform aerial surveys of several operational and non-operational reactor sites during the summer months of 1968.

The data collected on these surveys included aerial photographs of the installations, aerial radiation survey data consisting of exposure rates normalized to 3 feet above the ground plus gamma-ray spectral charts, effluent characterization for operational sites (intensity rates and isotope constituents), and pertinent descriptive information of the installation.
\end{abstract}

This report presents the data collected on the Big Rock Point reactor survey. 


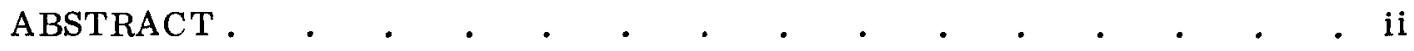

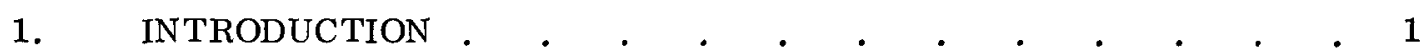

2. BIG ROCK POINT REACTOR AND SITE CHARACTERISTICS . - 2

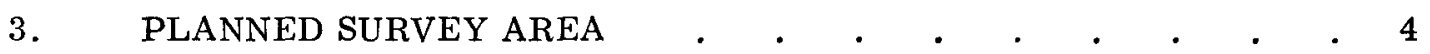

4. TERRESTRIAL RADIATION SURVEY • •

5. EFFLUENT CHARACTERIZATION •

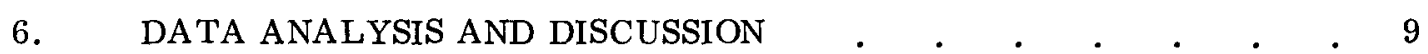

6.1 Gross-Count Data . . . . . . . . . . 9

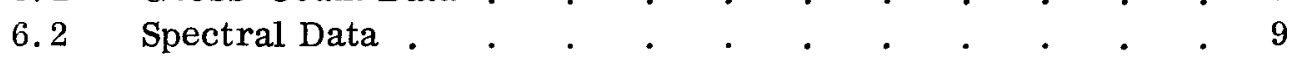

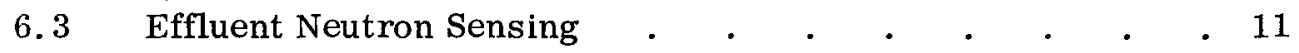

6.4 Effluent Gamma-Ray Measurements . . . . . . 11

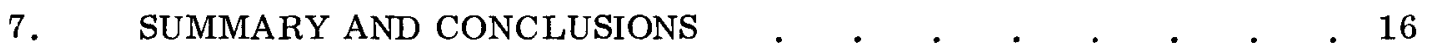

APPENDIX GAMMA-RAY SPECTRAL CHARTS . . . . . . 17
\end{abstract}

\title{
ILLUSTRATIONS
}

Figure $\quad \underline{\text { Page }}$

3-1 Planned survey area, Big Rock Point, Michigan . . . . 5

4-1 Flight lines - Big Rock Point reactor . . . . . . . 7

6-1 Exposure rate contours, Big Rock Point, 15 July 1968 • • . 10

6-2 Effluent plume, Big Rock Point reactor, 30 September 1968 . . 12

6-3 Effluent plume centerline spectra, Big Rock Point reactor, 30 September 1968 •

6-4 Air filter sample spectra of the plume of the Big Rock Point reactor, 30 September 1968 . . . . . . . . . 15 


\section{TABLES}

Table

Page

2-1 Population distribution - Big Rock Point survey area . . . 3

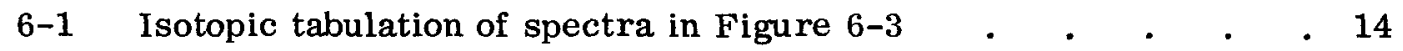

6-2 Isotopic tabulation of air filter spectra in Figure 6-4 $\quad$ - . . 14 
The Aerial Radiological Measuring System (ARMS), operated for the U. S. Atomic Energy Commission, was used to perform aerial surveys of several operational and non-operational reactor sites during the summer months of 1968 .

The data collected on these surveys provide a catalog file of characteristics of each nuclear installation. Information included in the catalog file consists of: 1) aerial photographs of the installation, 2) aerial radiation survey data consisting of exposure rates normalized to 3 feet above the ground plus gamma ray spectral charts, 3) effluent characterization for operational sites (intensity rates and isotope constituents), and 4) pertinent descriptive information of the installation. The ARMS equipment and procedures employed to conduct these surveys and evaluate the results are described in a previous EG\&G report. *

*Boyns, P. K.; Doyle, J. F.; and Sevart, M. D.; "Aerial Radiological Measuring Systems (ARMS) - Systems and Procedures Employed Through FY 1971," AEC Report No. ARMS-71.6, in preparation. 


\section{BIG ROCK POINT REACTOR AND SITE CHARACTERISTICS}

The Big Rock Point reactor site is located in North Central Michigan on the shoreline of Lake Michigan, 4 miles northeast of the community of Charlevoix. Currently operating at the site is a boiling water reactor with a capacity of $75 \mathrm{MW}(\mathrm{E})$ (gross) owned and operated by Consumers Power Company. With the exception of the community of Charlevoix, the area within a 10 -mile radius of the Big Rock Point reactor can be considered sparsely populated. Table $2-1$ presents a breakdown of the habitation of the region in terms of radial distance and direction from the reactor site. It is readily seen that 35 percent of the population live within a 10 -mile radius of the reactor installation. Approximately 50 percent of the area within a 15-mile radius of the reactor site is comprised of the open waters of Lake Michigan. The remainder of the area consists of rolling hills interspersed with numerous lakes, the largest being Lake Charlevoix in the South Central region. Also in evidence in the area are numerous small streams and swamps.

Radio towers widely scattered throughout the survey area seemed to be the only potential hazard to low-level flights. Of the four small airfields in the area, none seemed to generate any significant activity.

Aircraft refueling, routine servicing, and major repairs are available at the Traverse City and Alpena, Wisconsin airfields. Both of these airfields are located within 65 nautical miles of the reactor site. 
Table 2-1. Population distribution - Big Rock Point survey area.

\begin{tabular}{|c|c|c|c|c|}
\hline \multirow[b]{2}{*}{ Town } & \multirow{2}{*}{$\begin{array}{l}\text { Direction From } \\
\text { Reactor } \\
\end{array}$} & \multicolumn{3}{|c|}{ Radial Distance From Reactor (Miles) } \\
\hline & & $0-5$ & $5-10$ & $10-15$ \\
\hline & & \multicolumn{3}{|c|}{ Population } \\
\hline Bayshore & $\mathbf{E}$ & 250 & & \\
\hline Burgess & $\mathrm{SE}$ & 250 & & \\
\hline Charlevoix & SSW & 14,100 & & \\
\hline Advance & $\mathrm{S}$ & & 250 & \\
\hline Barnard & WSW & & 250 & \\
\hline Horton Bay & SE & & 250 & \\
\hline Ironton & $\mathbf{S}$ & & 250 & \\
\hline Phelps & S & & 250 & \\
\hline Atwood & SSW & & & 250 \\
\hline Boyne City & $\mathrm{SE}$ & & & 5,000 \\
\hline East Jordan & $\mathbf{S}$ & & & 5,000 \\
\hline Ellsworth & $\mathbf{S}$ & & & 1,000 \\
\hline Good Hart & NNE & & & 250 \\
\hline Harbor Springs & $\mathrm{NE}$ & & & 5,000 \\
\hline Menonaqua & ENE & & & 250 \\
\hline Patons Corner & $\mathrm{NE}$ & & & 250 \\
\hline Petosky & $\mathrm{E}$ & & & 10,000 \\
\hline Ramona & ENE & & & 250 \\
\hline Roaring Brook & ENE & & & 250 \\
\hline Stutsmanville & NNE & & & 250 \\
\hline Wequetonsing & ENE & & & 250 \\
\hline Wildwood & $\mathrm{SE}$ & & & 250 \\
\hline \multicolumn{2}{|l|}{ Totals } & 14,600 & 1,250 & 28,250 \\
\hline
\end{tabular}




\section{PLANNED SURVEY AREA}

The survey area planned for the Big Rock Point reactor site included flying all land areas within a 25-mile square centered over the reactor site. (See Figure 3-1.) Flight lines were planned to provide flight paths spaced at 1-mile intervals. The resultant grid included 21 east-west oriented lines varying in length from 7 to $23 \mathrm{~N}$. miles. These lines constituted the programmed grosscount and spectral environmental radiation survey.

Pre-planning for the effluent tracking and neutron sensing surveys consisted of locating the reactor site on appropriate topographic maps and performing realtime analys is of local meteorological conditions. 


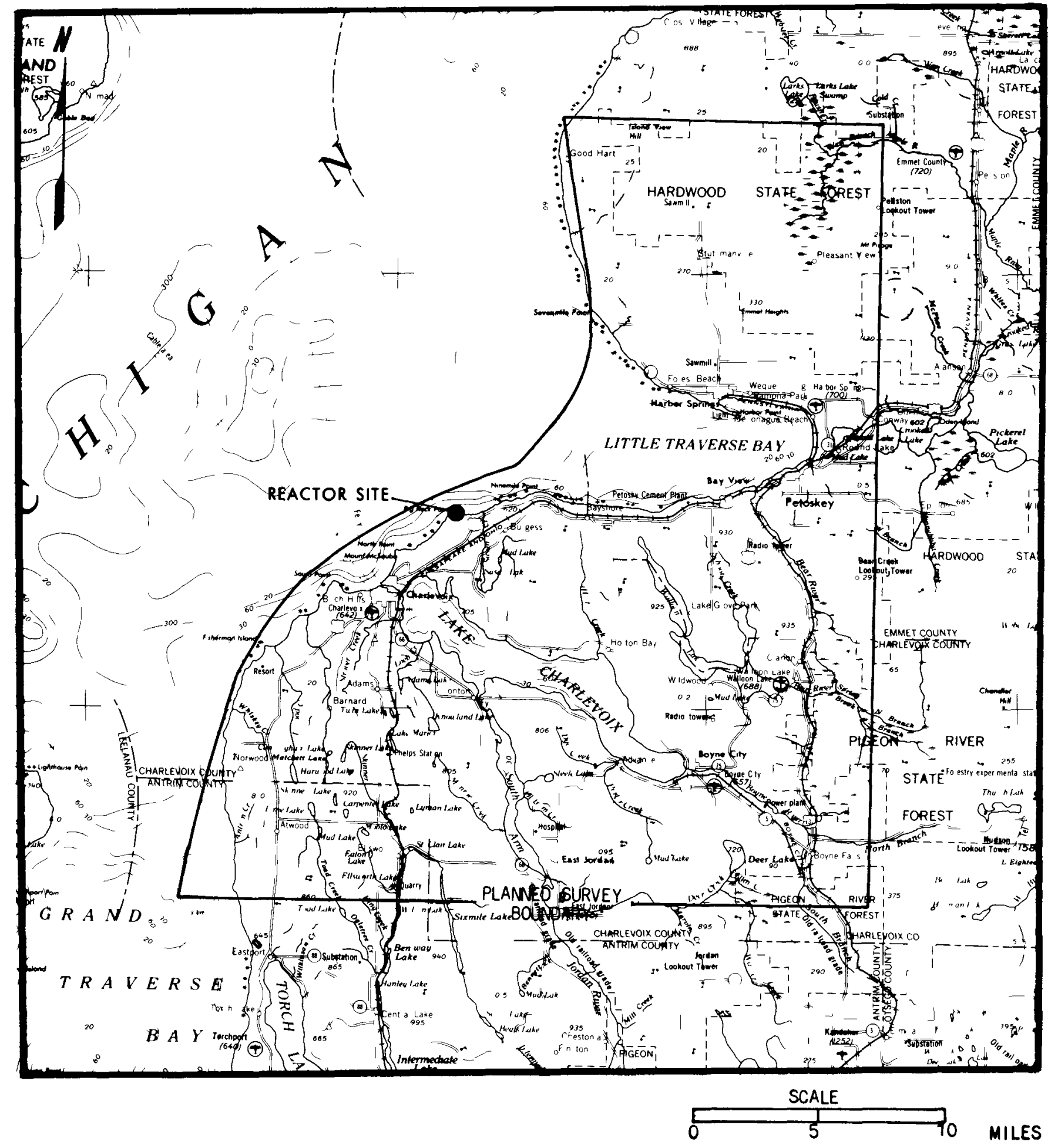

Figure 3-1. Planned survey area, Big Rock Point, Michigan. 


\section{TERRESTRIAL RADIATION SURVEY}

The terrestrial radiation survey to collect gross-count and spectral data of the Big Rock Point area was flown on 15 July 1968. The reactor was not operating on that day.

The selected flight altitude for data collection was $300 \mathrm{ft}$ above the terrain to provide simultaneous collection of gross-count and spectral data. All flight lines were flown similar to those programmed. Figure 4-1 shows the actual flight lines plotted from recorded position information.

Spectral collections were accumulated over a 4-minute live-time period. This corresponds to a distance of approximately 12 miles at survey aircraft speed. Where flight lines were shorter than 12 miles, a 4-minute collection was obtained by continuing to accumulate data on the following line. 


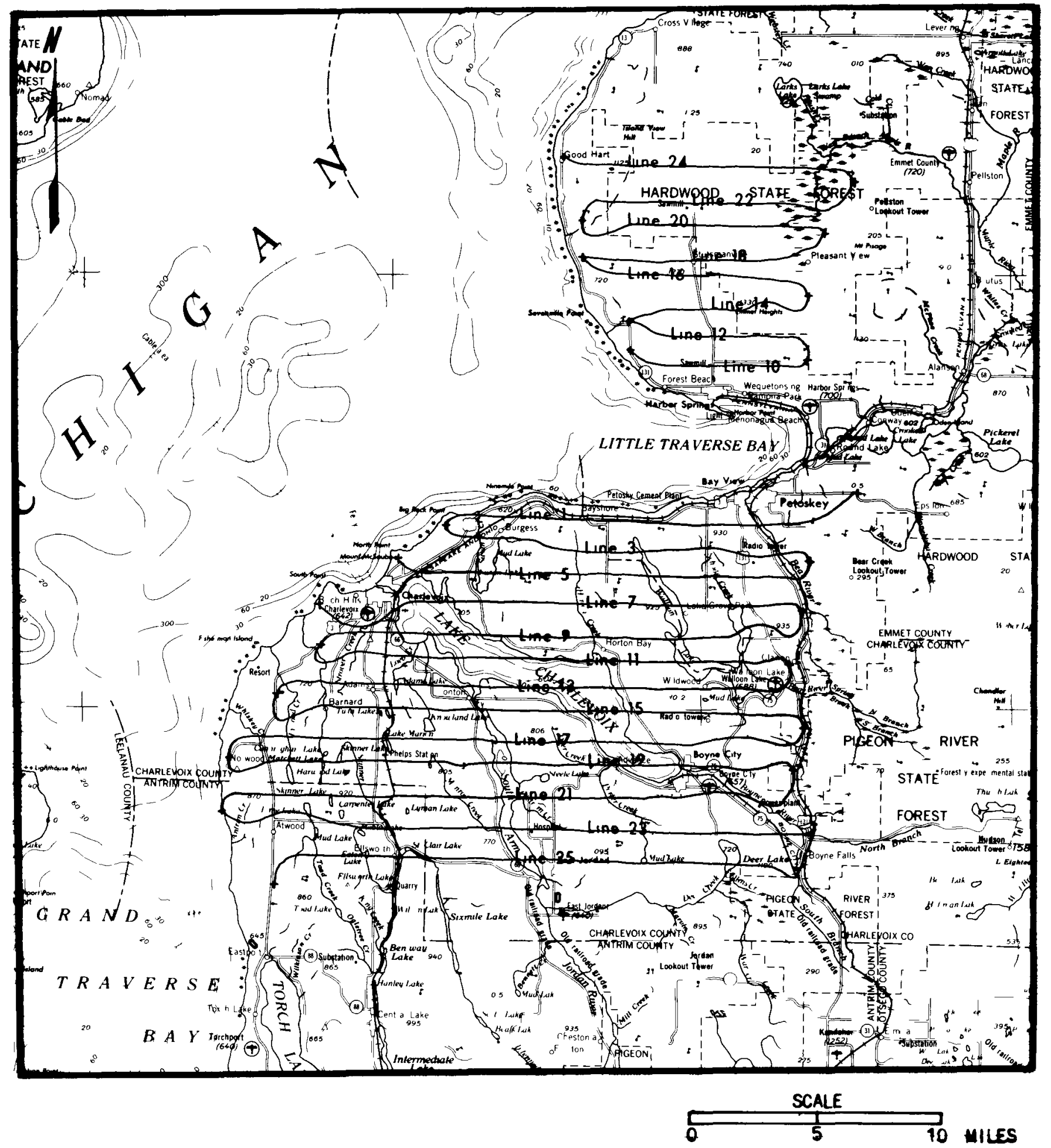

Figure 4-1. Flight lines - Big Rock Point reactor. 


\section{EFFLUENT CHARACTERIZATION}

A mission to document effluent characteristics and radiation signature was flown on 30 September 1968. In-plume neutron measu rements were made for comparison with measurements from an area upwind from the reactor installation. Following an inflight equipment change, the gamma-ray detection equipment was utilized to outline the effluent boundaries and obtain gross-gamma intensities. Spectral collections and air-filter samples were taken along the effluent centerline and periphery. At the time the plume track was performed, the reactor was at full power with a release rate of approximately $5,000 \mu \mathrm{Ci} / \mathrm{cc}$. 


\section{DATA ANALYSIS AND DISCUSSION}

The data recorded on all survey missions have been compiled and analyzed to provide a summary of environmental radiation characteristics relevant to the Big Rock Point reactor site. These results as recorded will provide baseline data should future surveys be conducted in this area.

\section{1 GROSS-COUNT DATA}

Figure 6-1 shows the resultant radiation pattern mapped from the data recorded. The exposure rate values are in $\mu \mathrm{R} / \mathrm{hr}$, at the 3 -foot level above the terrain.

The average exposure rate values for most of the area appear to be in the 4 to $6 \mu \mathrm{R} / \mathrm{hr}$ range. Results for areas with lower than average intensities can be attributed to the many lakes and marshy areas interspersed throughout the survey area.

The exposure rate data is a composite of the gamma rays eminating from the terrestrial surface plus the cosmic ray contribution which normally constitutes approximately 2 to $4 \mu \mathrm{R} / \mathrm{hr}$ of the total.

\subsection{SPECTRAL DATA}

The spectral data collected provide characteristic isotopic contributions from the grid line area flown as part of the terrestrial radiation survey. These spectral traces are included in the Appendix and the table preceding the traces lists the energies and isotopes present in all of these charts. The isotopic constituents appear to be consistent between the charts although individual intensities vary in some instances. Only significant photopeak energies of each nuclide have been included in the tabulation.

Three energies evident in all spectra taken during the terrestrial radiation survey were a direct result of on-board calibration sources. The isotopes and their associated energies are as follows: CS-137, $0.66 \mathrm{MeV}$; Co-60, 1.17 MeV; Co-60, 1.33 MeV. These sources were removed for the effluent characterization mission.

Background spectral collections were recorded prior to each survey mission at altitudes free from terrestrial effects. 


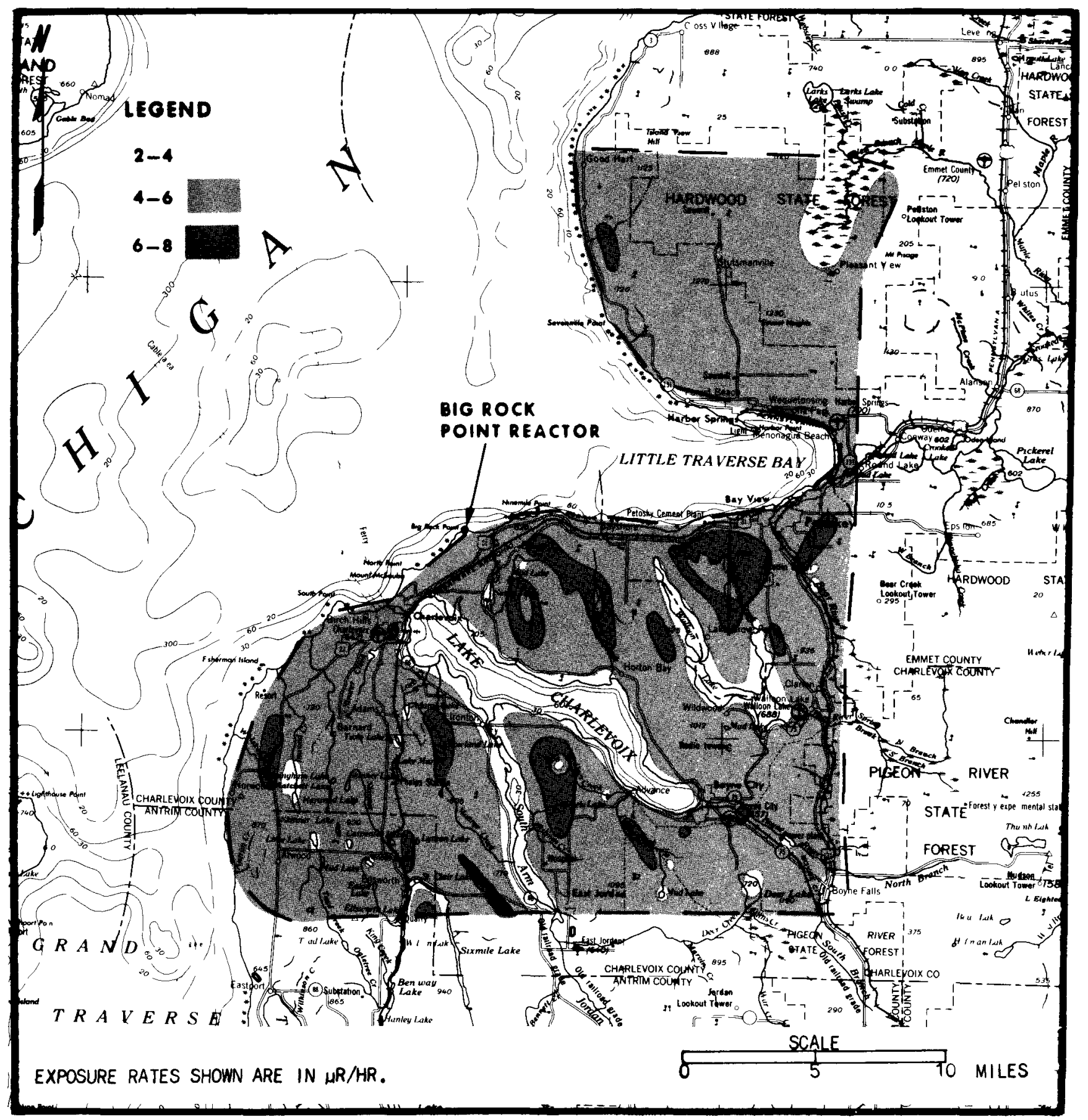

Figure 6-1. Exposure rate contours, Big Rock Point reactor, 15 July 1968. 
Since the presence of delayed neutron emitters in the downwind effluent would suggest a possible filter failure, it is believed that neutron measu rements in the plume could be a meaningful contribution to the characterization endeavor. The results of the collections made in the effluent showed an absence of the delayed neutron emitters. The neutron activity appeared consistent with the background collections made in the areas remote from the effluent.

\subsection{EFFLUENT GAMMA-RAY MEASUREMENTS}

The effluent plume as outlined by gamma-ray detection equipment is illustrated in Figure 6-2. This pattern will vary, of course, with changing meteorological conditions and reactor release rates.

After completing a peripheral track, penetrations along the centerline were made to record gross-count intensities, collect air filter samples, and accumulate spectral information. The maximum gross-count intensity recorded along the centerline was approximately 10 to 15 times background.

The spectral data collected along the effluent centerline are shown in Figure 6-3. The spectral data shown in Figure 6-3 was accumulated with the crystal array. Table 6-1 lists the isotopes identified from the energies present in this spectral trace.

Gamma ray analysis of the exposed air-filter samples was performed immediately upon their removal from the air stream. The resultant spectral trace is shown in Figure 6-4, and Table 6-2 lists the isotopes identified from the energies present. The spectral data in Figure 6-4 was accumulated using a $3 \times 3$ inch crystal with an air filter placed on the face of the crystal in a plastic dish. These filter samples were returned to Las Vegas laboratory analysis to search for possible long-lived contributors. This analysis was performed approximately 2 weeks after collection and showed no significant activity.

The complex direct emission spectra obtained during effluent characterization makes a qualitative isotopic interpretation difficult because of the resolution of sodium iodide crystals. The direct emission spectra contains both gaseous and particulate isotopes; however, the air filter spectra contains only the particulate isotopes. This enhances the capability of interpretation of the complex direct emission spectra. Also, the identification of prominent members of decay series aids in the identification of other members of the series, which must be present and are not as easily recognized from the spectral data. 


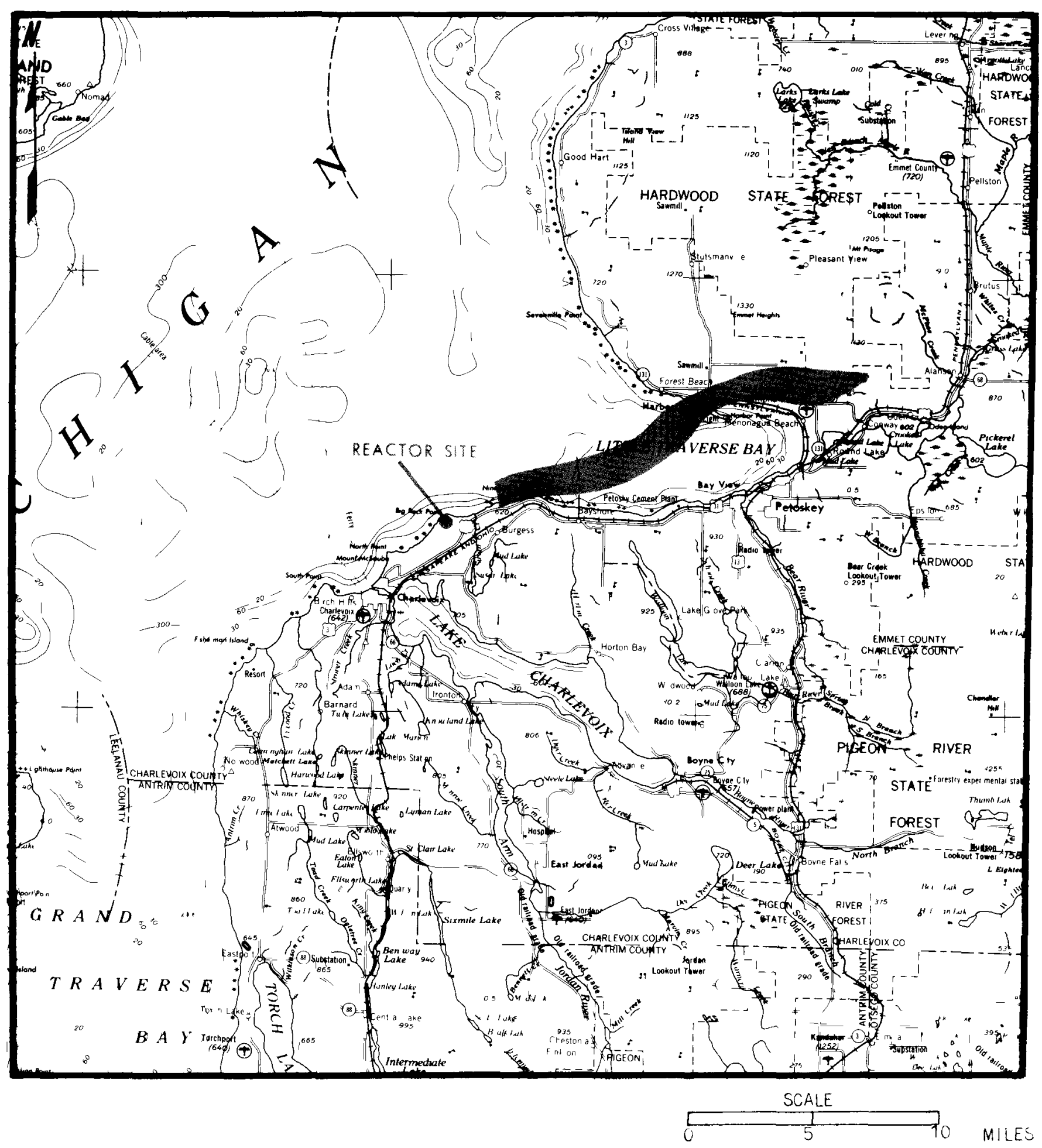

Figure 6-2. Effluent plume, Big Rock Point reactor, 30 September 1968. 


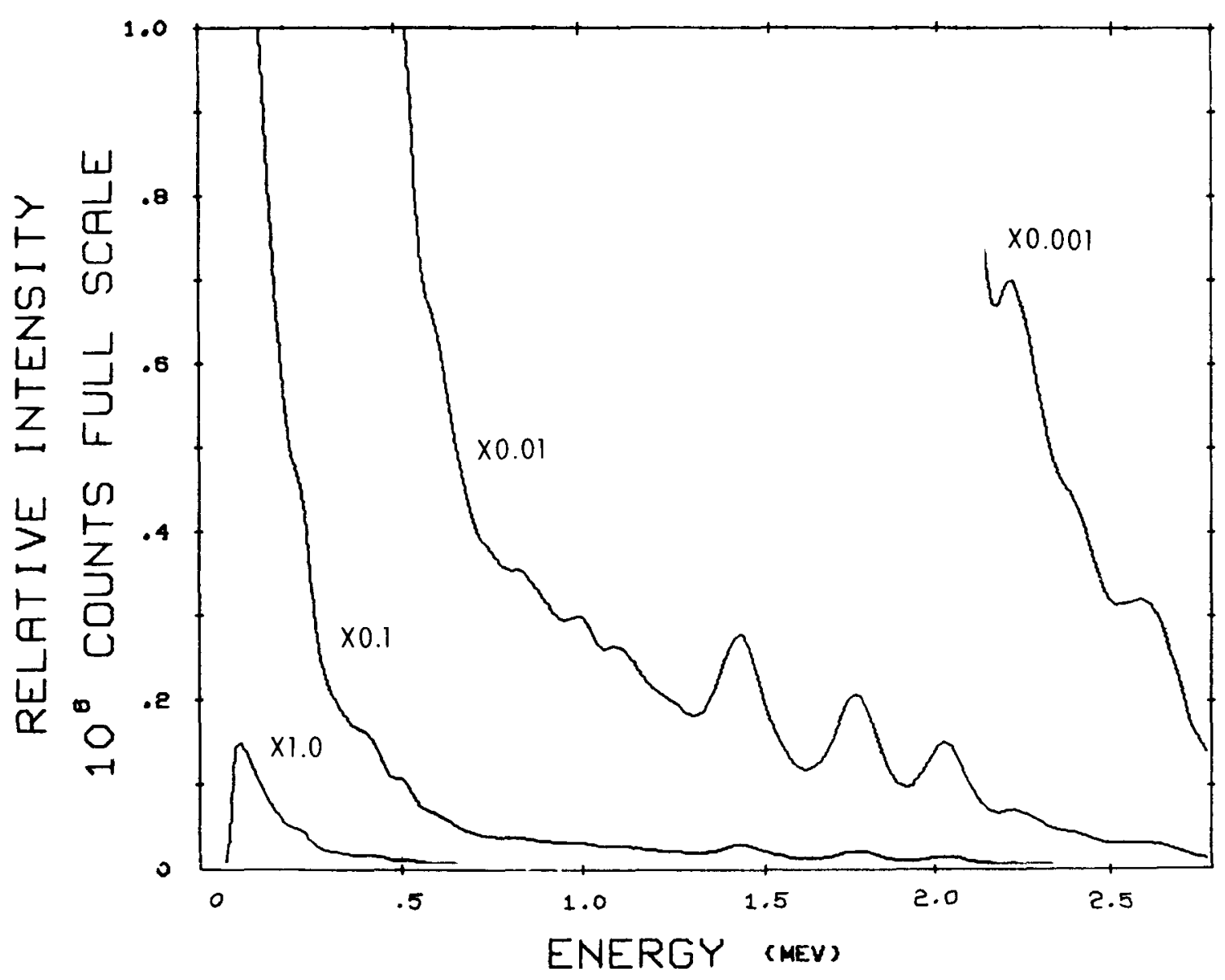

Figu re 6-3. Effluent plume centerline spectra, Big Rock Point reactor, 30 September 1968. 
Table 6-1. Isotopic tabulation of spectra in Figure 6-3.

\begin{tabular}{|c|c|c|c|}
\hline \multirow{2}{*}{$\begin{array}{c}\text { Obs. } \\
\text { Energy } \\
(\mathrm{MeV})\end{array}$} & \multicolumn{3}{|c|}{ Radionuclides Consistent with Spectral Photopeaks } \\
\hline & Fission Products & $\begin{array}{l}\text { Activation } \\
\text { Products }\end{array}$ & Background \\
\hline $\begin{array}{r}0.25 \\
0.40-0.46 \\
0.51-0.55 \\
0.61 \\
0.65-0.66 \\
0.75 \\
0.85-0.91 \\
1.02-1.05 \\
1.12 \\
1.42-1.55 \\
1.75-1.85 \\
2.01-2.11 \\
2.20 \\
2.40 \\
2.57-2.68\end{array}$ & 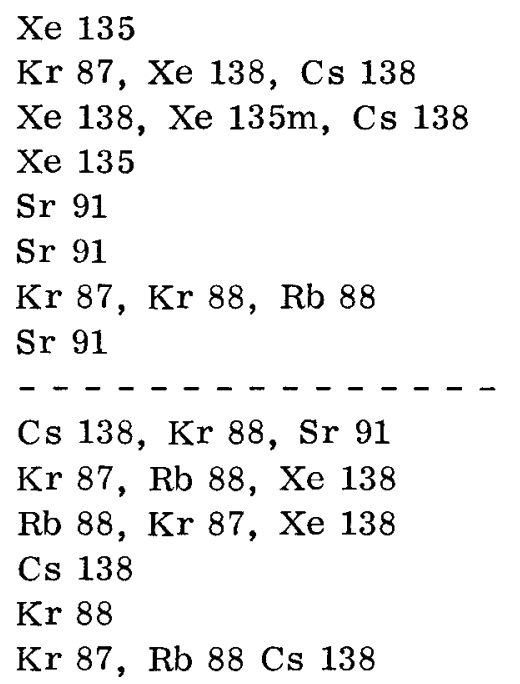 & & $\begin{array}{l}\text { Bi } 214 \\
\text { K } 40 \\
\text { Bi } 214 \\
\text { B } 214\end{array}$ \\
\hline
\end{tabular}

Table 6-2. Isotopic tabulation of air filter spectra in Figure 6-4.

\begin{tabular}{|l|l|r|l|}
\hline \multirow{2}{*}{$\begin{array}{c}\text { Obs. } \\
\text { Energy } \\
(\text { MeV) }\end{array}$} & \multicolumn{3}{|c|}{ Radionuclides Consistent with Spectral Photopeaks } \\
\cline { 2 - 4 } & \multicolumn{1}{|c|}{ Fission Products } & $\begin{array}{c}\text { Activation } \\
\text { Products }\end{array}$ & Background \\
\hline $0.46-0.65$ & CS $138+\operatorname{Sr} 91$ & & \\
$0.75-0.93$ & Sr $91+\operatorname{Rb} 88$ & & \\
$1.01-1.03$ & Sr $91+\operatorname{Cs~} 138$ & & \\
$1.41-1.43$ & Sr $91+\operatorname{Cs~} 138$ & & \\
1.86 & Rb 88 & & \\
2.21 & Cs 138 & & \\
$2.63-2.68$ & Rb $88+\operatorname{Cs~} 138$ & & \\
\hline
\end{tabular}




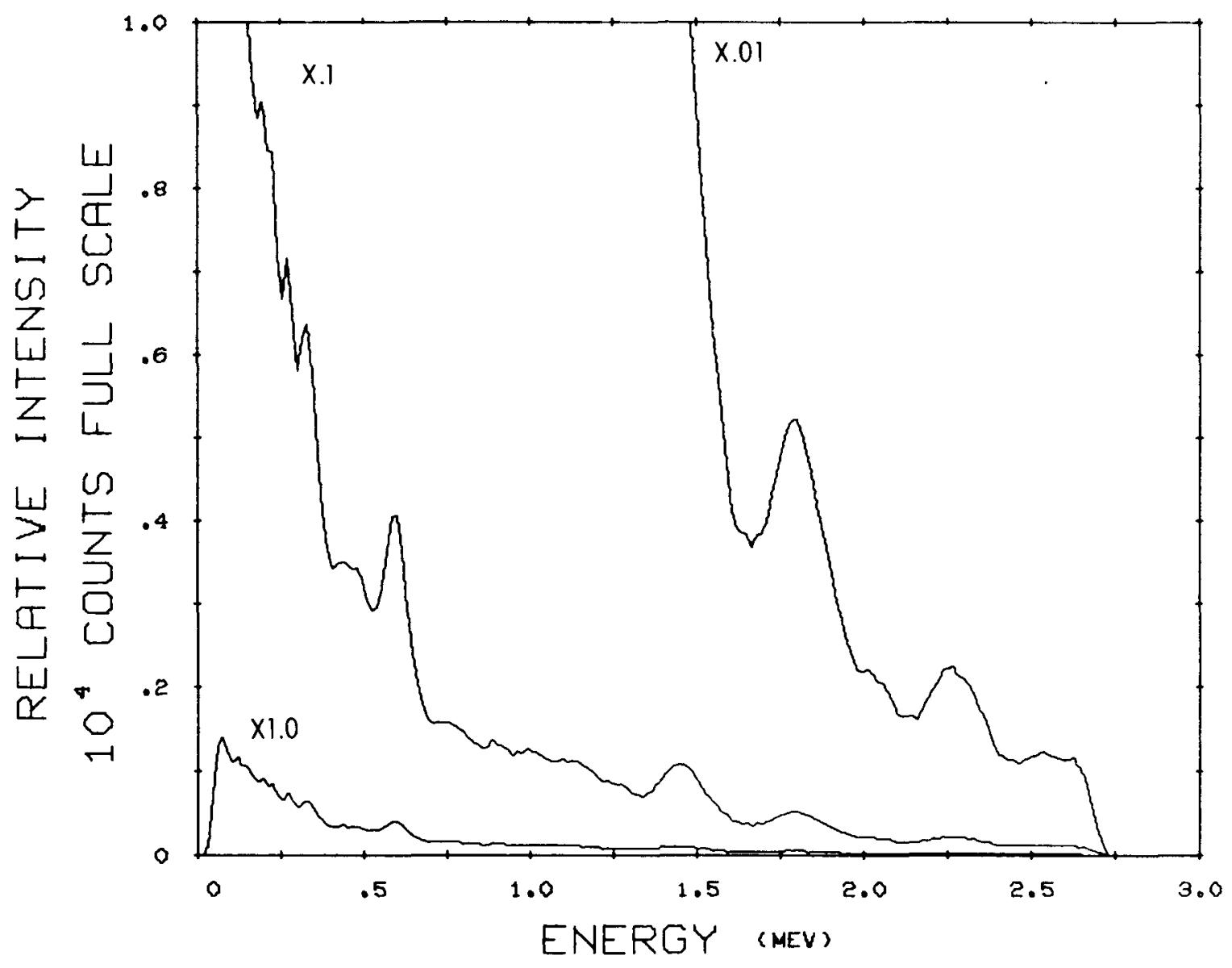

Figure 6-4. Air filter sample spectra of the plume of the Big Rock Point reactor, 30 September 1968. 


\section{SUMMARY AND CONCLUSIONS}

The Big Rock Point power reactor site was surveyed from the air during both operational and non-operational status. Results of the survey can be summarized as follows:

1. The terrestrial radiation survey was performed during a nonoperational mode. The exposure rates mapped during the survey were predominantly in the $4-$ to $6-\mu \mathrm{R} / \mathrm{hr}$ range. No anomalies were detected that might be attributed to Big Rock Point reactor operations.

2. The effluent plume was tracked 15 to 20 miles downwind of the reactor stack. Effluent characteristics were obtained by spectral analysis and air-filter sample collections. No significant indication of longlived fission product activity was observed on the air filter samples.

3. No significant indication of delayed neutron emitters were detected in the downwind effluent. 


\section{APPENDIX \\ GAMMA-RAY SPECTRAL CHARTS}

The gamma-ray spectral charts that constitute this section are included to show energy characteristics of the flight lines making up the environmental radiation survey area of the Big Rock Point reactor.

The tabulation preceding the total group of spectra shows the energies present in all charts and lists the isotopic contributor believed to be associated with the photopeaks observed.

\begin{tabular}{|l|l|l|l|}
\hline \multirow{2}{*}{$\begin{array}{c}\text { Obs. } \\
\text { Energy } \\
(\mathrm{MeV})\end{array}$} & \multicolumn{3}{|c|}{ Radionuclides Consistent with Spectral Photopeaks } \\
\cline { 2 - 4 } & Fission Products & $\begin{array}{c}\text { Activation } \\
\text { Products }\end{array}$ & Background \\
\hline 0.51 & & & Annih. \\
$0.61-67$ & & & $\mathrm{Bi}-214+\mathrm{Cs}-137$ \\
$1.12-1.17$ & & & $\mathrm{Bi}-214+\mathrm{Co}-60$ \\
$1.33-1.46$ & & & $\mathrm{Co}-60+\mathrm{K}-40$ \\
1.76 & & & $\mathrm{Bi}-214$ \\
2.20 & & & $\mathrm{~T} 1-208$ \\
2.62 & & & \\
\hline
\end{tabular}




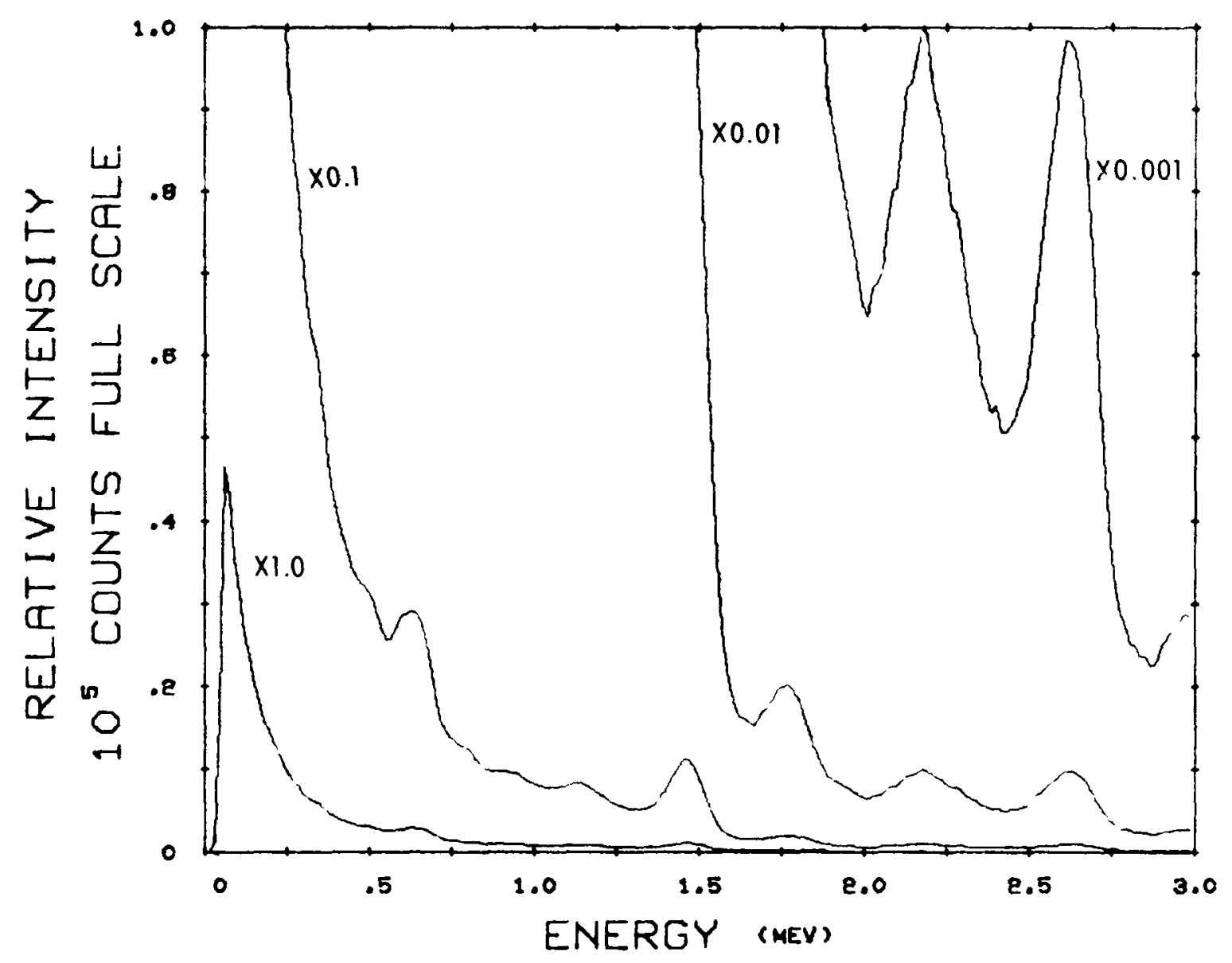

LOCATION: LINE 24 (ENTIRE FLIGHT LINE)

LINE 22 (EASTERN HALF)

SPECTRUM NO. 702

DATE OP-15-68

LIVE TIME 4.00

INTEGRATED CT。 513640

TYPE ACFT TERRAIN BKG。-GND。DEPO.

RLTITUDE $\quad 300$

AIRCRAFT (ARMS) 


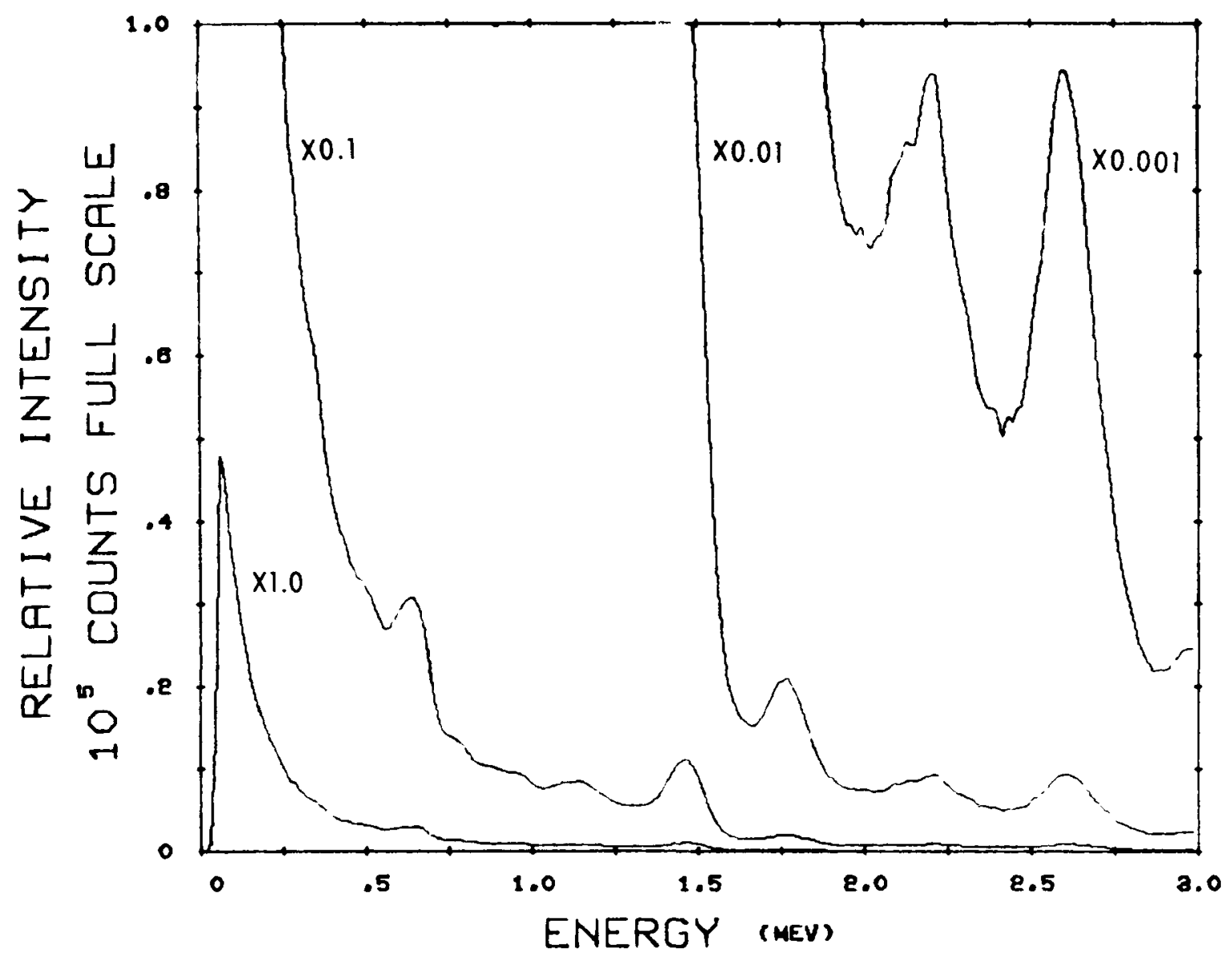

LOCATION: LINE 22 (WESTERN HALF)

LINE 20 (WESTERN HALF)

SPECTRUM NO. 703

DATE O7-15-68

LIVE TIME $\quad 4.00$

INTEGRATED CT. 529186

TYPE ACFT TERRAIN BKG。-GND。DEPO. ALTITUDE 300

AIRCRAFT (ARMS) 


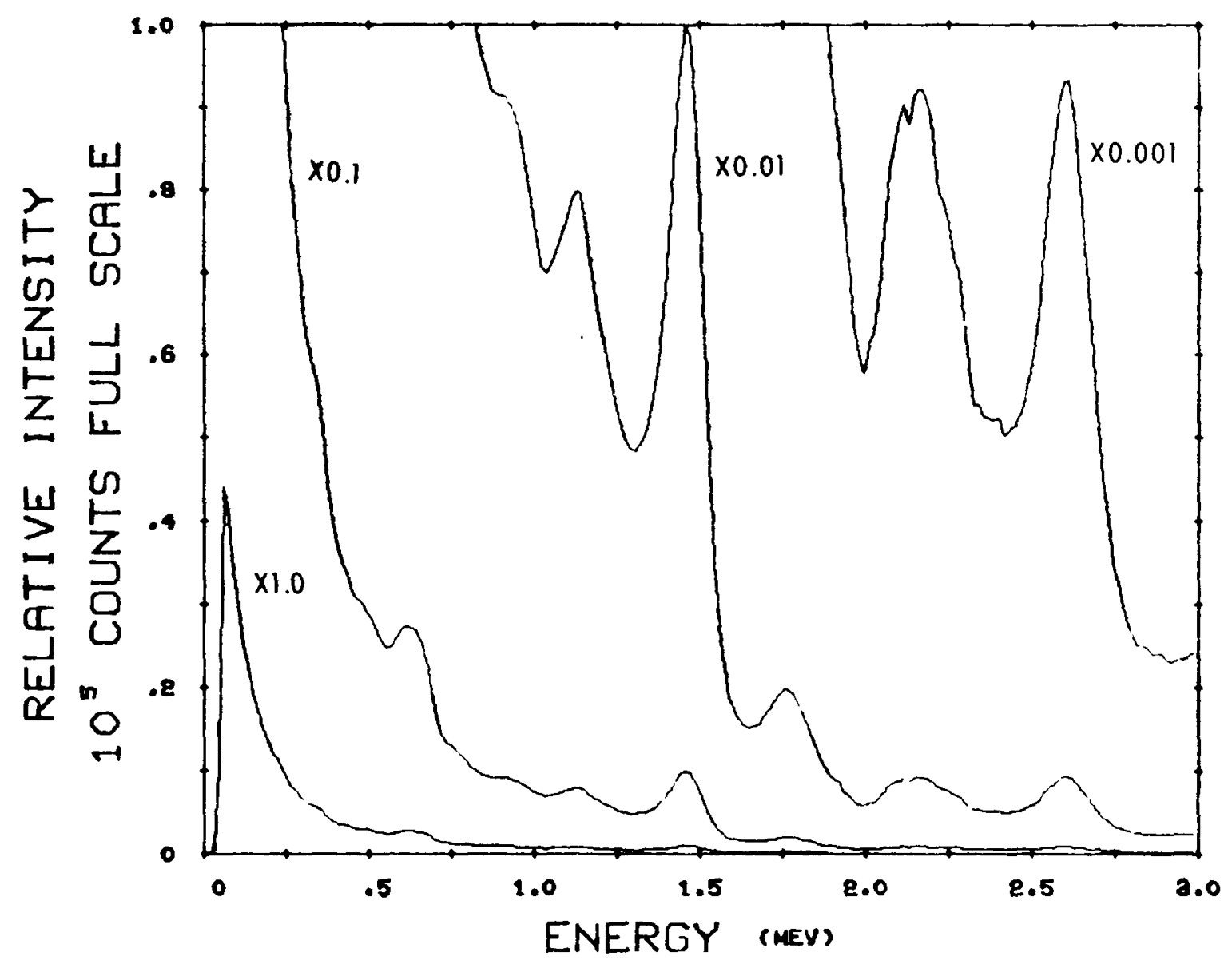

LOCATION: LINE 20 (EASTERN HALF) LINE 18 (ENTIRE FLIGHT LINE)

SPECTRUM NO. 704

DATE O7-15-68

LIVE TIME 4.00

INTEGRATED CT. 477914

TYPE ACFT TERRAIN BKG.-GND. DEPO. ALTITUDE 300

AIRCRAFT (ARMS) 


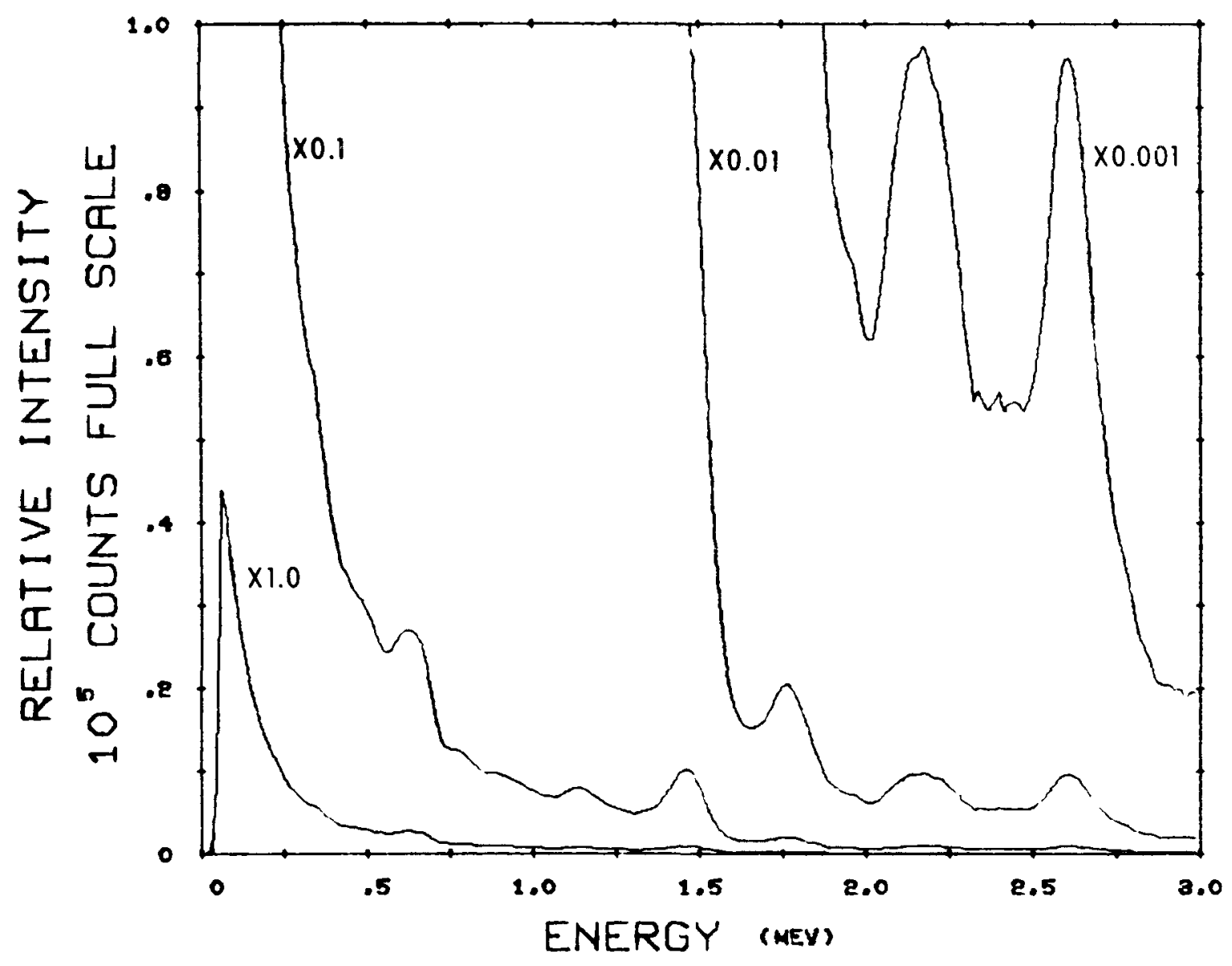

LOCATION: LINE 16 (ENTIRE FLIGHT LINE)

LINE 14 (EASTERN HALF)

SPECTRUM NO. 705

DATE OT-15-68

LIVE TIME 4.00

INTEGRATED CT. 486481

TYPE ACFT TERRAIN BKG。-GND。DEPO。 ALTITUDE $\quad 300$

AIRCRAFT (ARMS) 


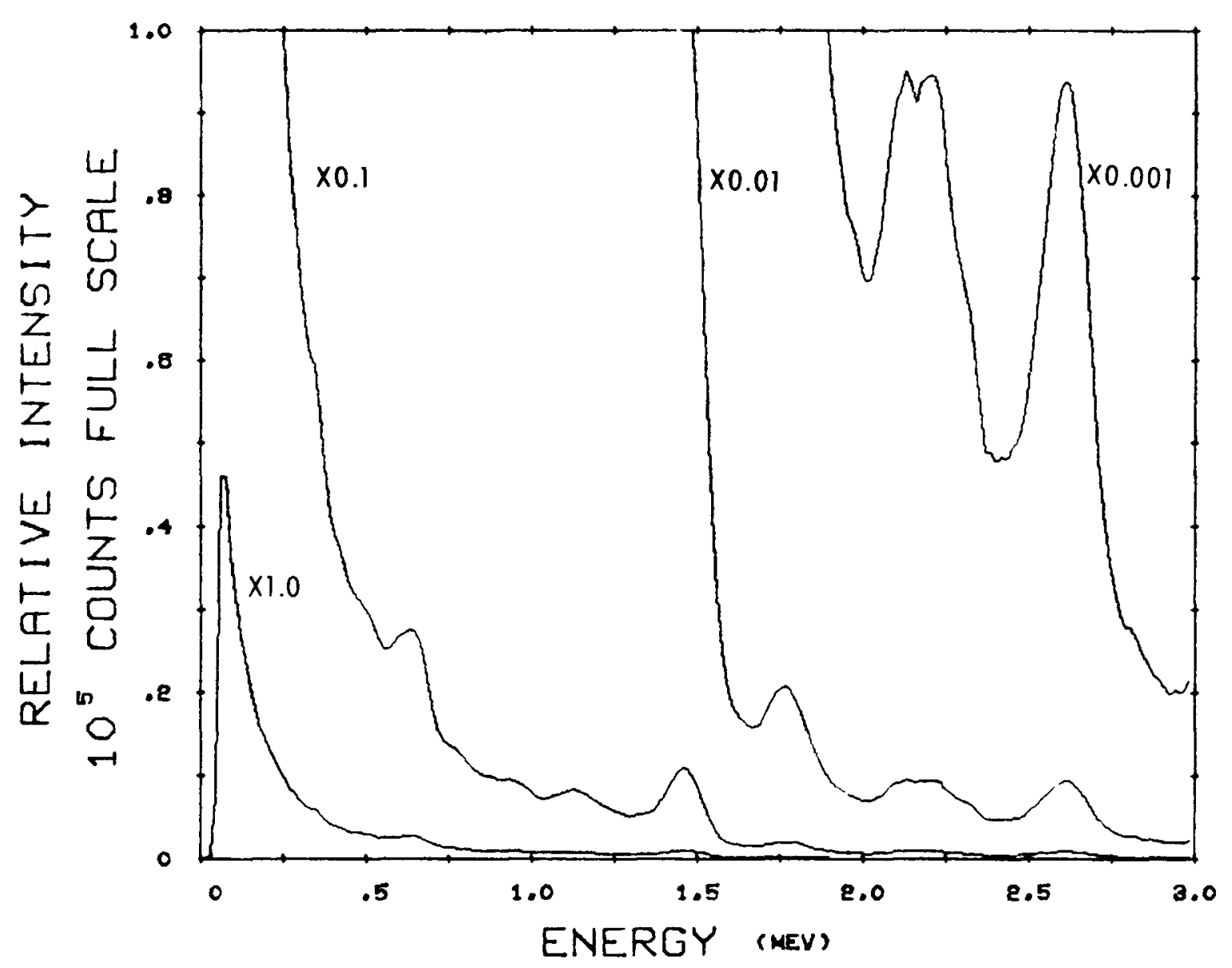

LOCATION: LINE 14 (WESTERN HALF)

LINE 12 (WESTERN HALF)

SPECTRUM NO. 706

DATE OP-15-68

LIVE TIME $\quad 4.00$

INTEGRATED CT. 504043

TYPE ACFT TERRAIN BKG.-GND. DEPO.

ALTITUDE

AIRCRAFT

300

( ARMS) 


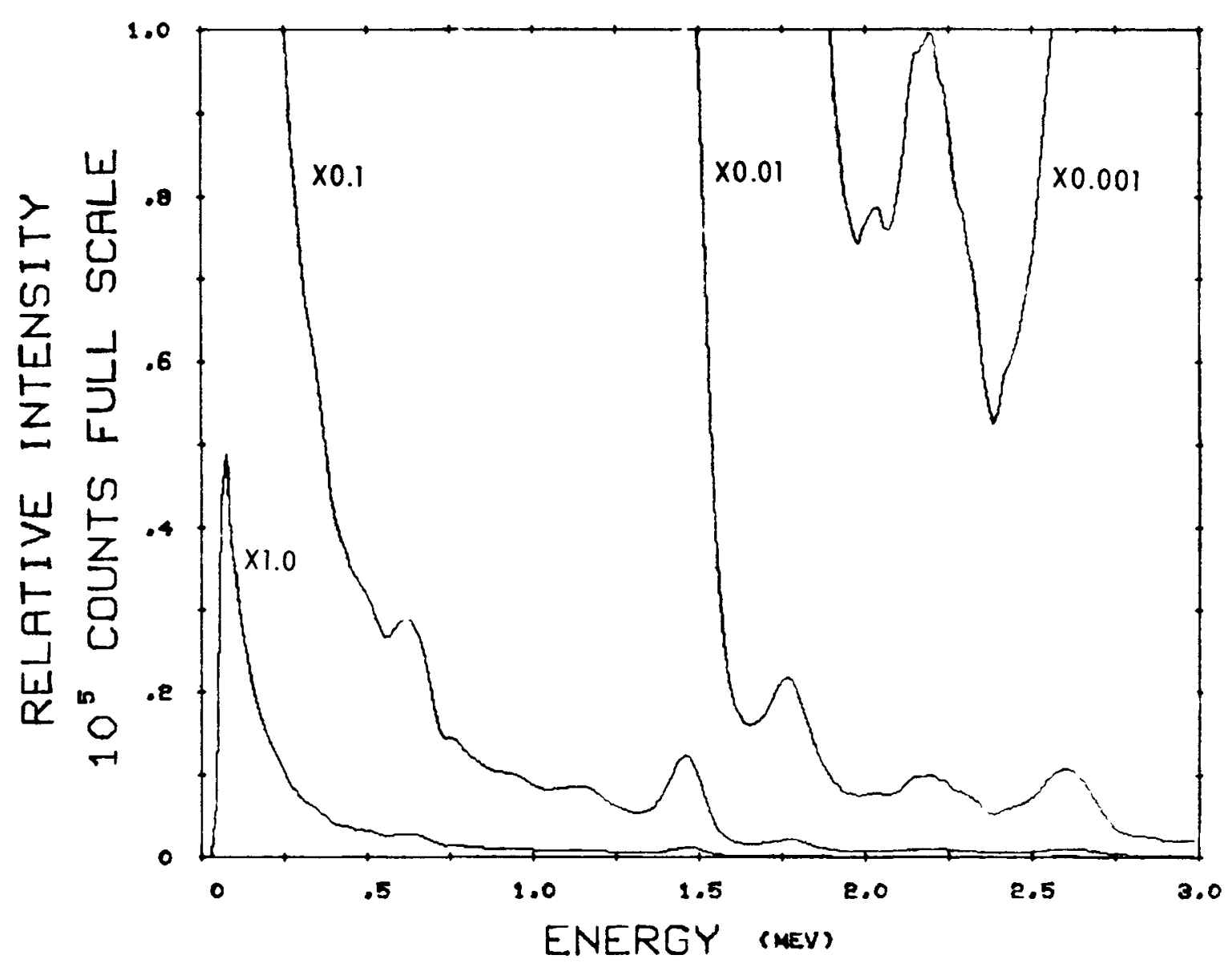

LOCATION: LINE 12 (EASTERN HALF) LINE 10 (ENTIRE FLIGHT LINE)

SPECTRUM NO. 707

DATE O7-15-68

LIVE TIME 4.00

INTEGRATED CT. 526019

TYPE ACFT TERRAIN BKG。-GND。DEPO. ALTITUDE $\quad 300$ AIRCRAFT ( RRMS) 


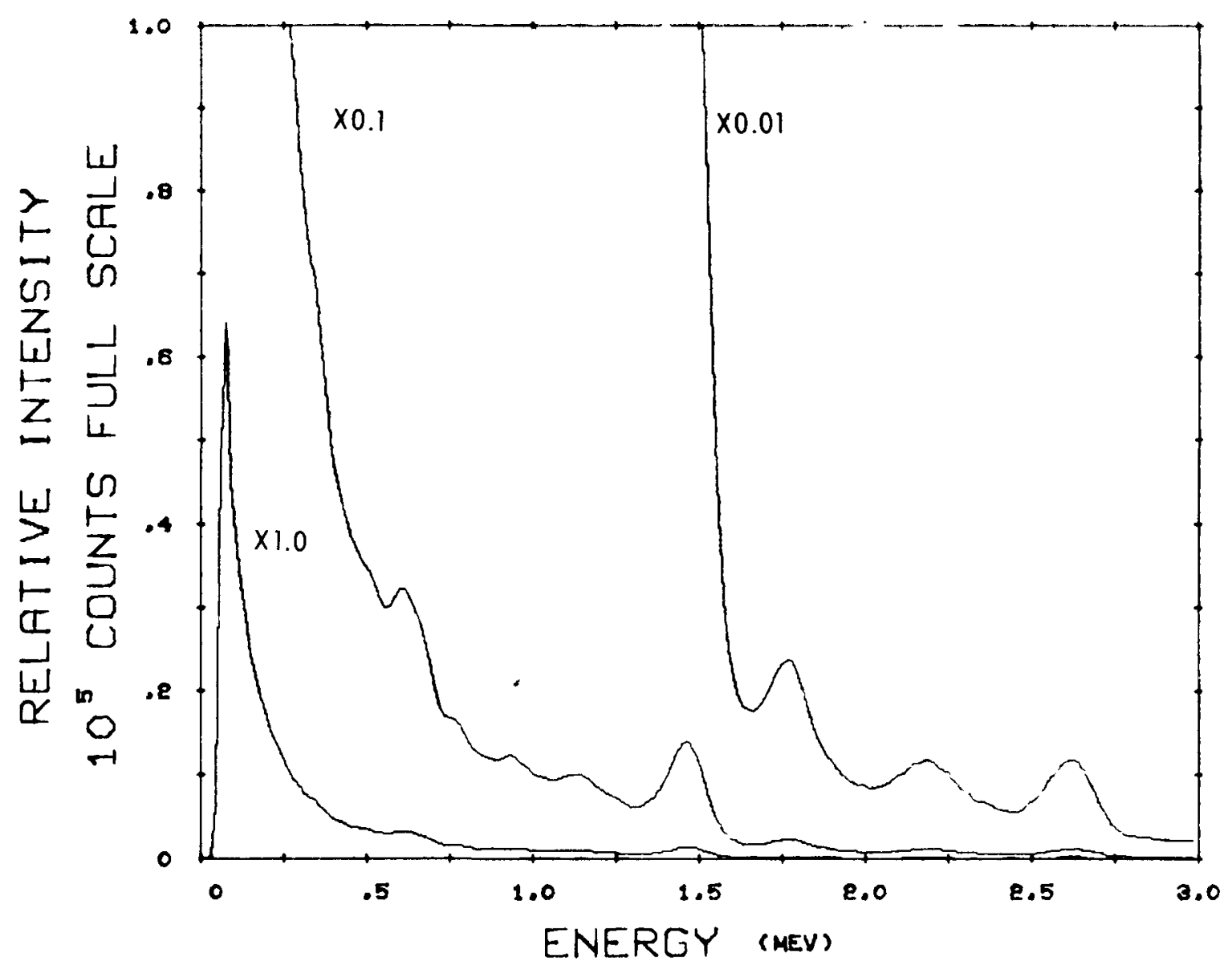

LOCATION: LINE I (ENTIRE FLIGHT LINE)

SPECTRUM NO. 708

DATE O7-15-68

LIVE TIME 4.00

INTEGRATED CT。 607455

TYPE ACFT TERRAIN BKG.-GND。DEPO. RLTITUDE 300

AIRCRAFT (ARMS) 


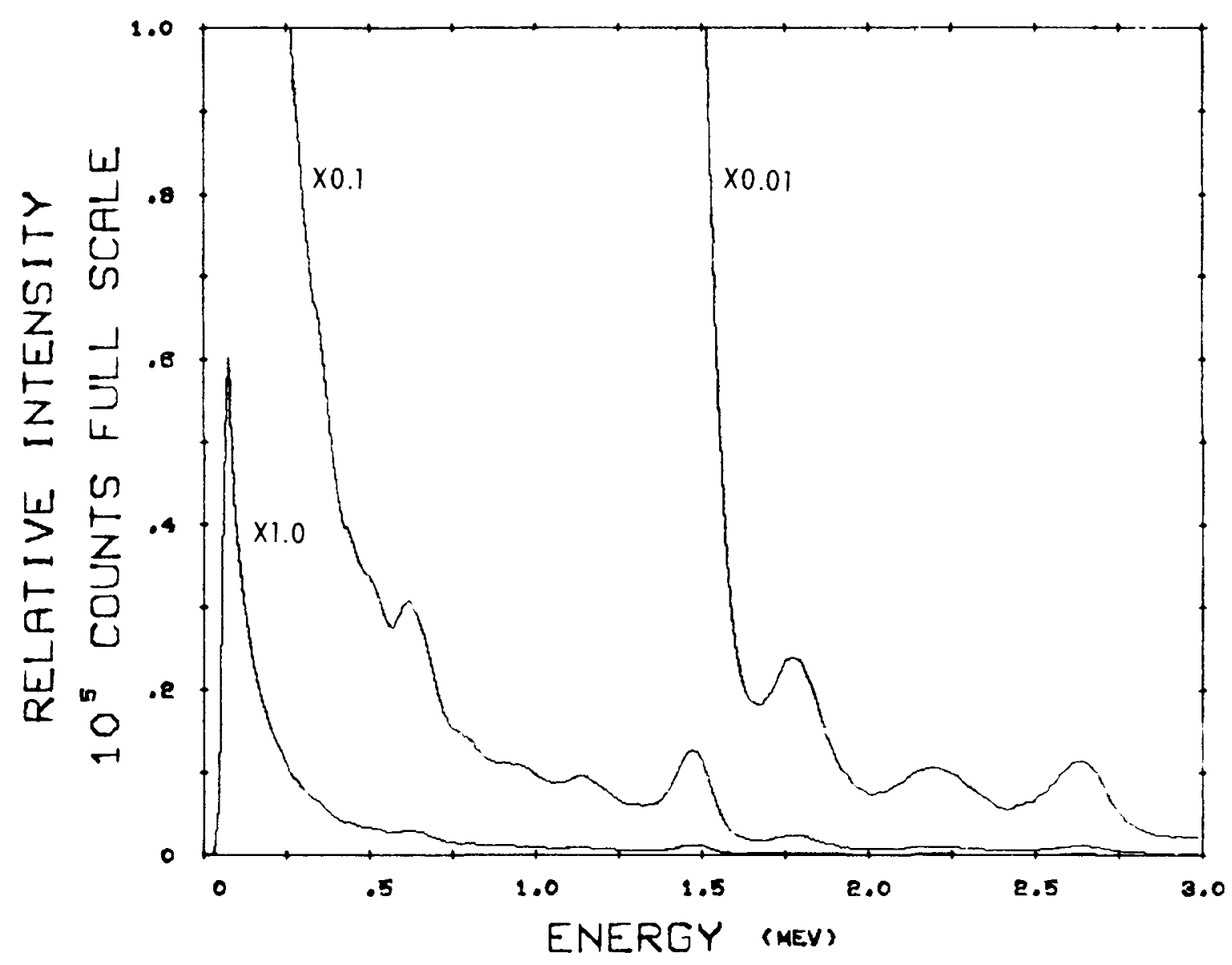

LOCATION: LINE 3 (ENTIRE FLIGHT LINE)

SPECTRUM NO. 709

DATE OP-15-68

LIVE TIME 4.00

INTEGRATED CT. 572338

TYPE ACFT TERRAIN BKG.-GND. DEPO. ALTITUDE 300 AIRCRAFT (ARMS) 


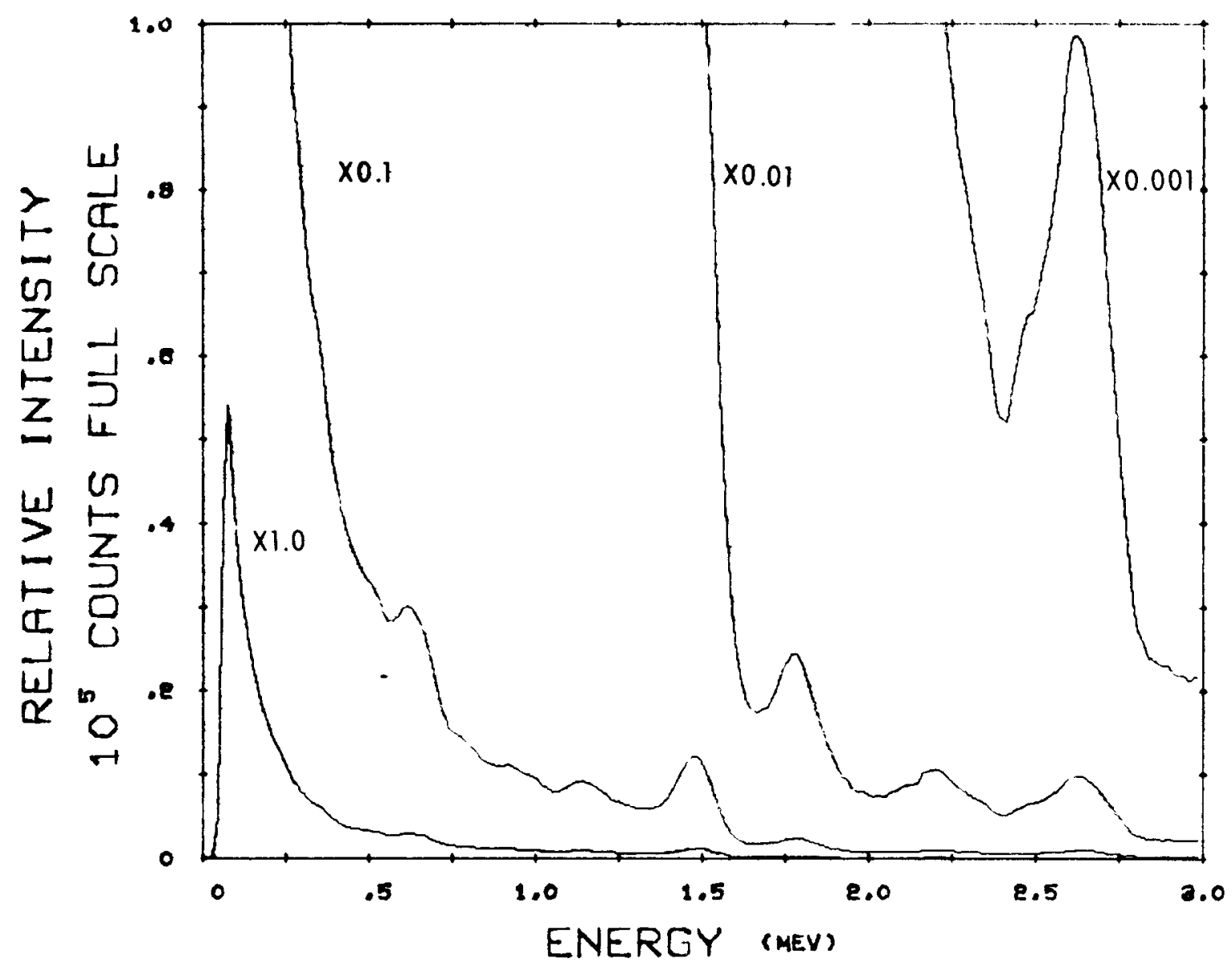

LOCATION: LINE 5 (ENTIRE FLIGHT LINE)

SPECTRUM NO. 710

DATE OP-15-68

LIVE TIME 4.00

INTEGRATED CT. 558246

TYPE ACFT TERRAIN BKG.-GNO. DEPO. ALTITUDE 300

AIRCRAFT (ARMS) 


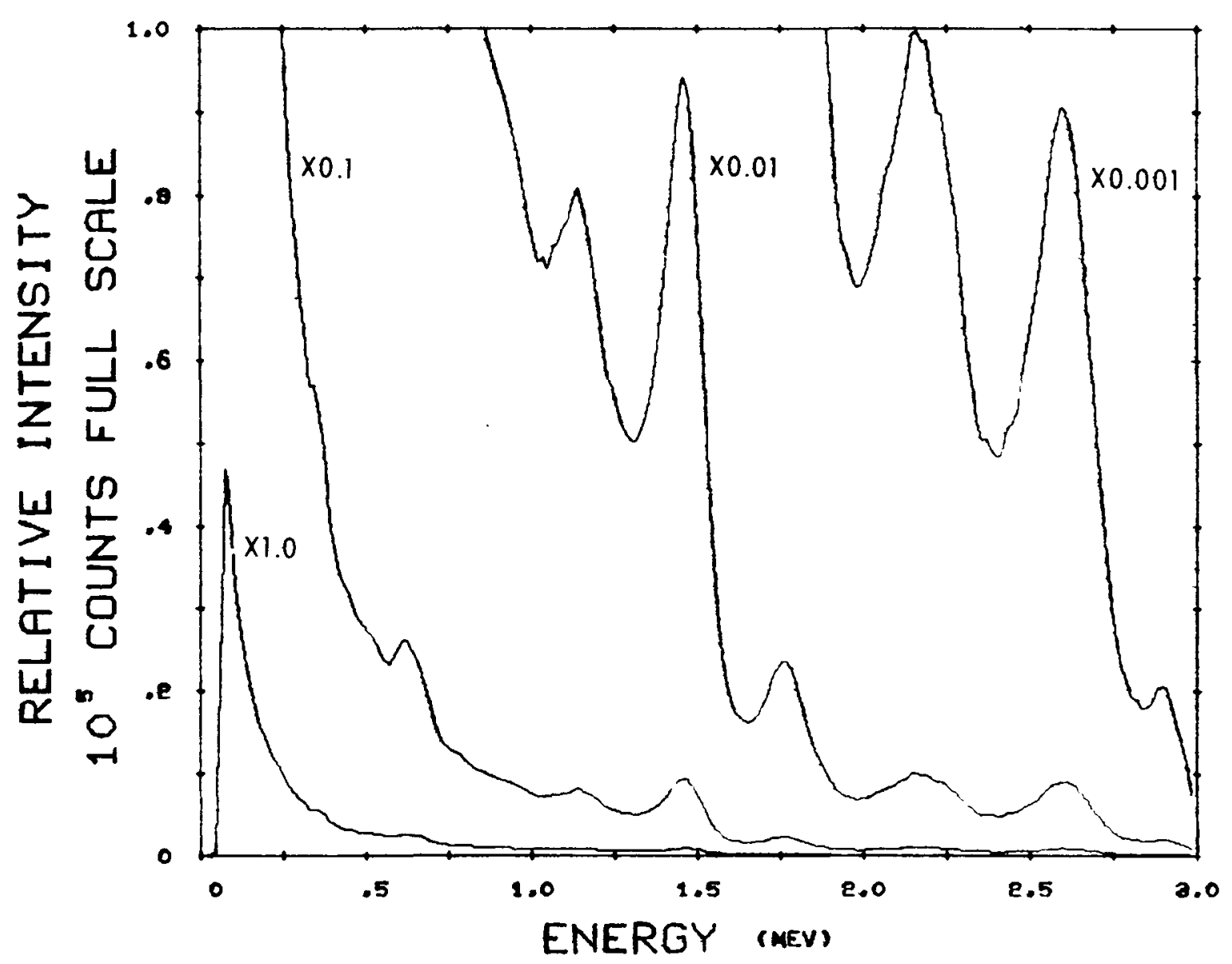

LOCATION: LINE 7 (ENTIRE FLIGHT LINE)

SPECTRUM NO. 711

DATE O7-15-68

LIVE TIME 4.00

INTEGRATED CT. $\quad 473664$

TYPE ACFT TERRAIN BKG。-GND。DEPO. ALTITUDE $\quad 300$ AIRCRAFT (ARMS) 


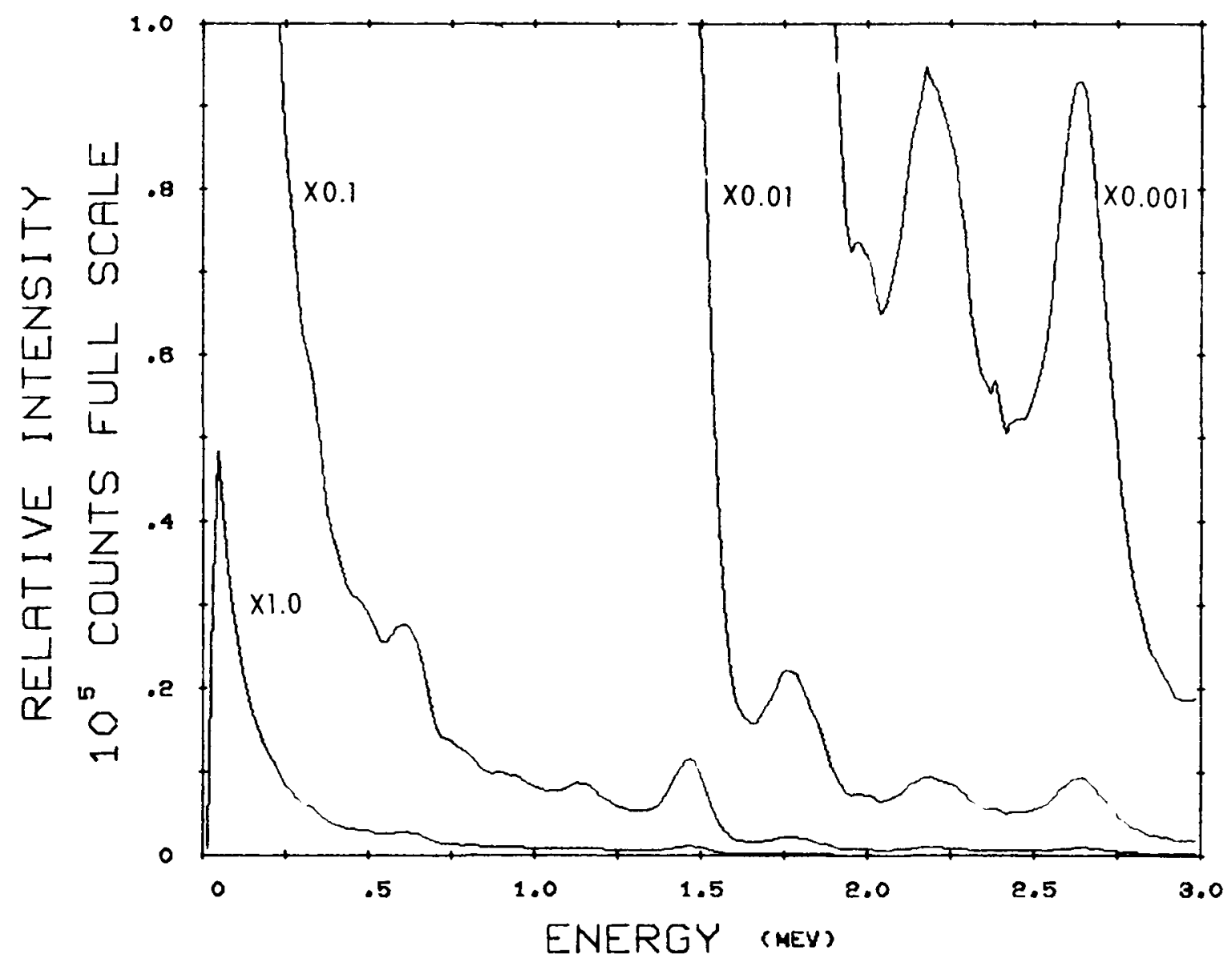

LOCATION: LINE 9 (ENTIRE FLIGHT LINE)

SPECTRUM NO. 712

DATE O7-15-68

LIVE TIME $\quad 4.00$

INTEGRATED CT。 516567

TYPE ACFT TERRAIN BKG。-GND。 DEPO。

ALT I TUDE

AIRCRAFT (ARMS) 


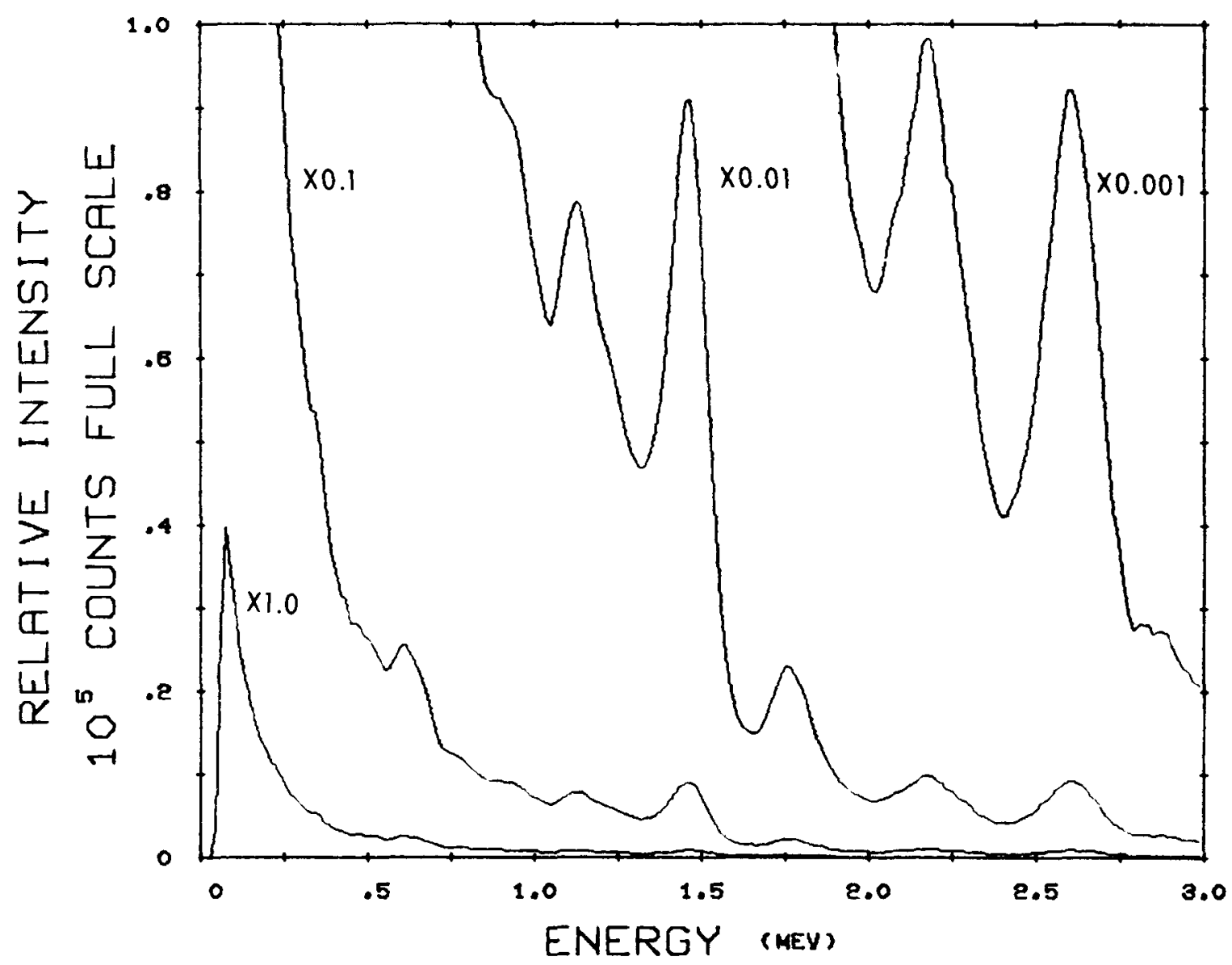

LOCATION: LINE $\|$ (ENTIRE FLIGHT LINE)

SPECTRUM NO. 713

DATE O7-15-68

LIVE TIME 4.00

INTEGRATED CT。 439503

TYPE ACFT TERRAIN BKG.-GND。DEPO. ALTITUDE $\quad 300$ AIRCRAFT (ARMS) 


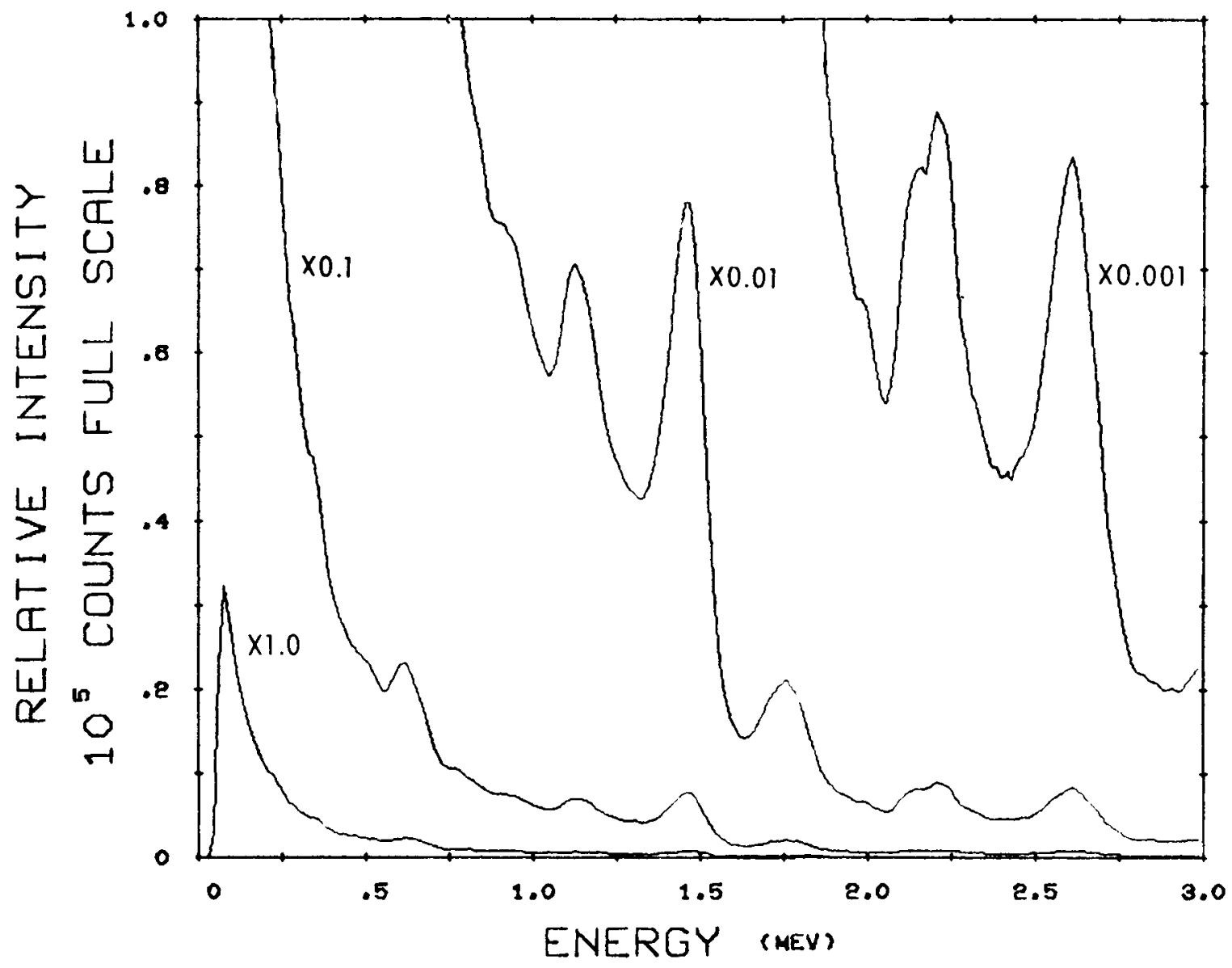

LOCATION: LINE 13 (ENTIRE FLIGHT LINE)

SPECTRUM NO. 714

DATE O7-15-68

LIVE TIME 4.00

INTEGRATED CT. 378177

TYPE ACFT TERRAIN BKG。-GND。DEPO. ALTITUDE 300 AIRCRAF $T$ (ARMS) 


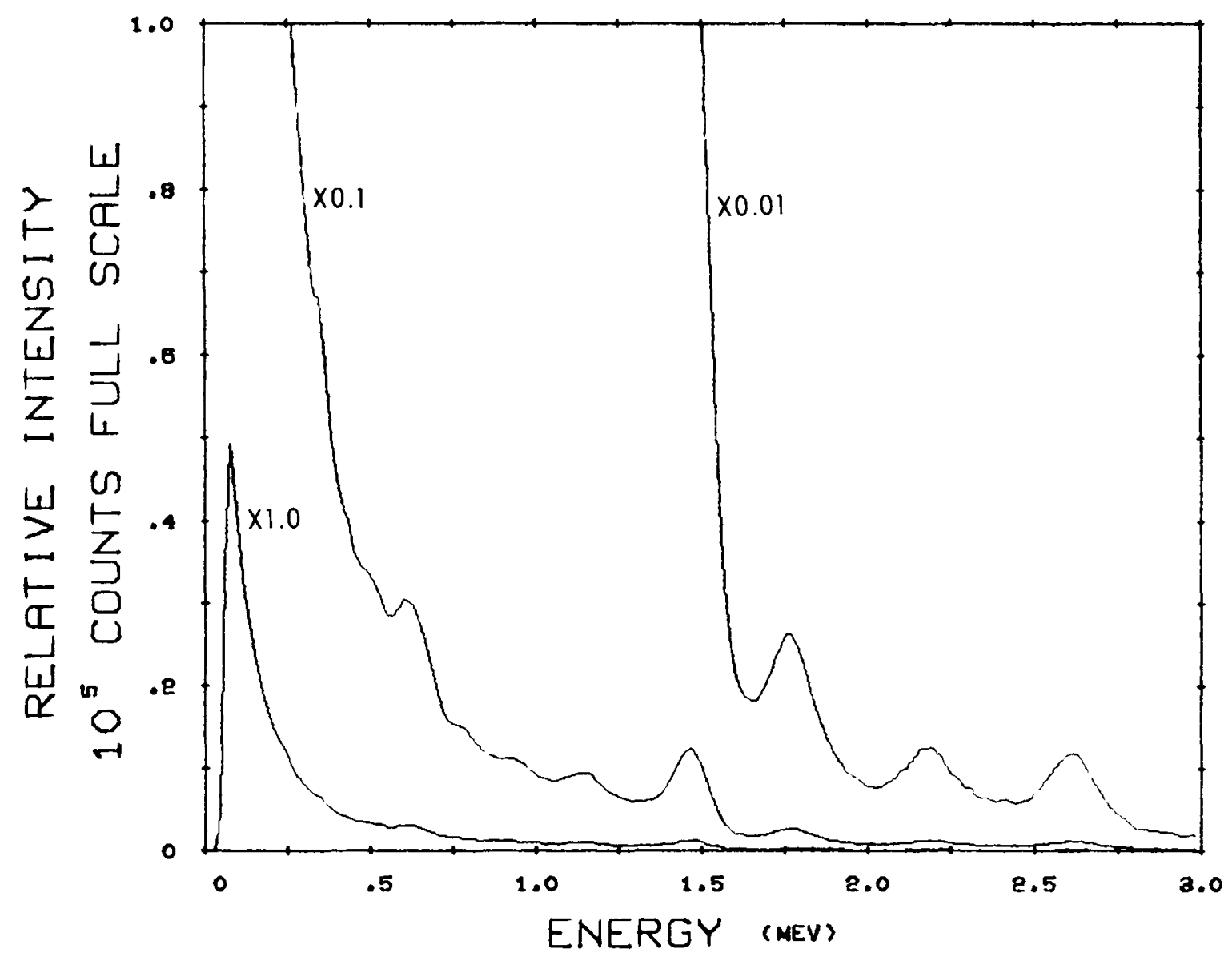

LOCATION: LINE 15 (ENTIRE FLIGHT LINE)

SPECTRUM NO。 715

DATE OP-15-68

LIVE TIME 4.00

INTEGRATED CT. 552308

TYPE ACFT TERRAIN BKG.-GND。DEPO. ALTITUDE 300

AIRCRAFT (ARMS) 


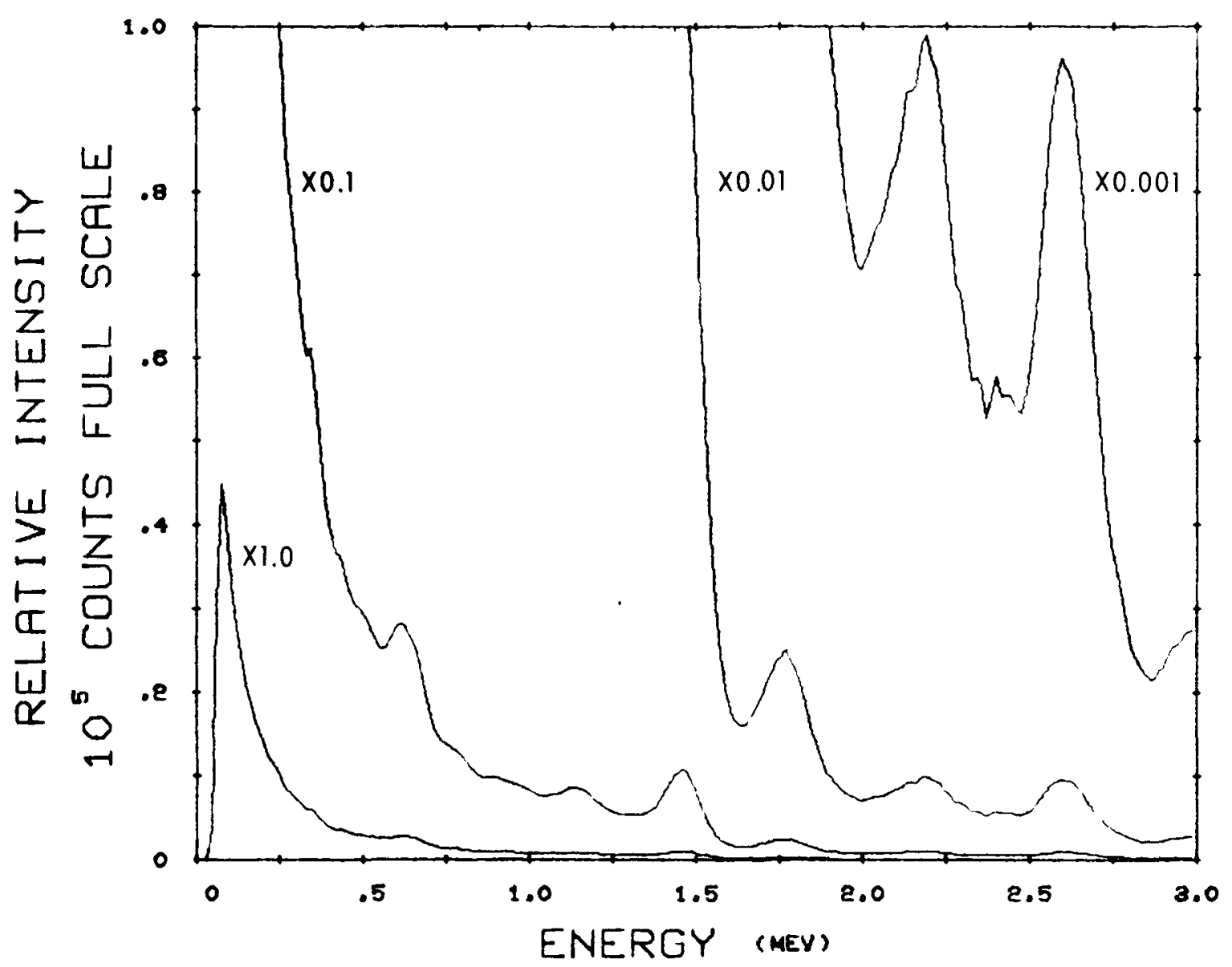

LOCATION: LINE 17 (ENTIRE FLIGHT LINE)

SPECTRUM NO. 716

DATE OP-15-68

LIVE TIME 4.00

INTEGRATED CT. 492931

TYPE ACFT TERRAIN BKG。-GND。DEPO. ALTITUDE 300 AIRCRAFT (ARMS) 


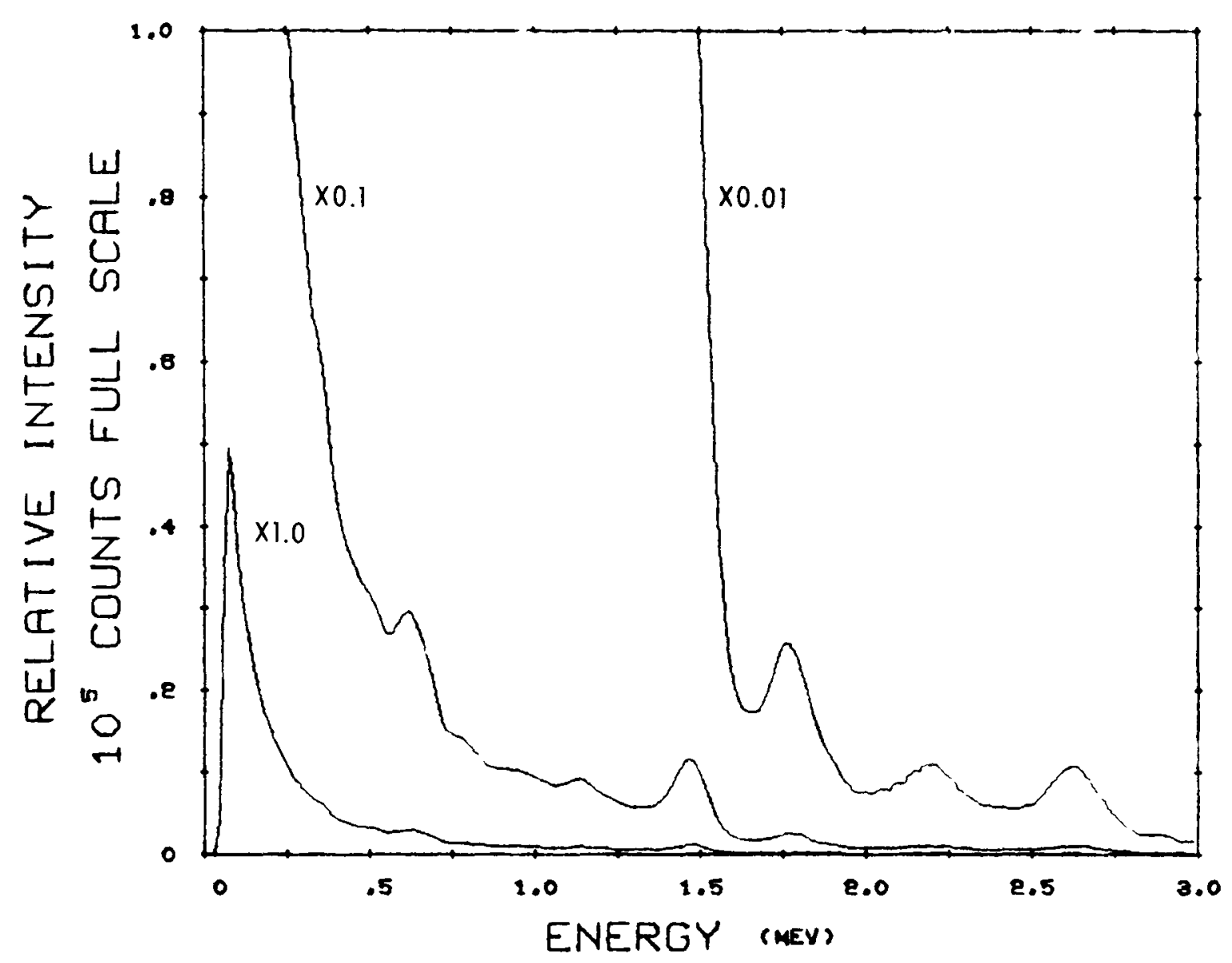

LOCATION: LINE 19 (ENTIRE FLGHT LINE)

SPECTRUM NO. 717

DATE O7-15-68

LIVE TIME 4.00

INTEGRATEO CT. 534470

TYPE ACFT TERRAIN BKG.-GND. DEPO. ALTITUDE 300

AIRCRAFT (ARMS) 


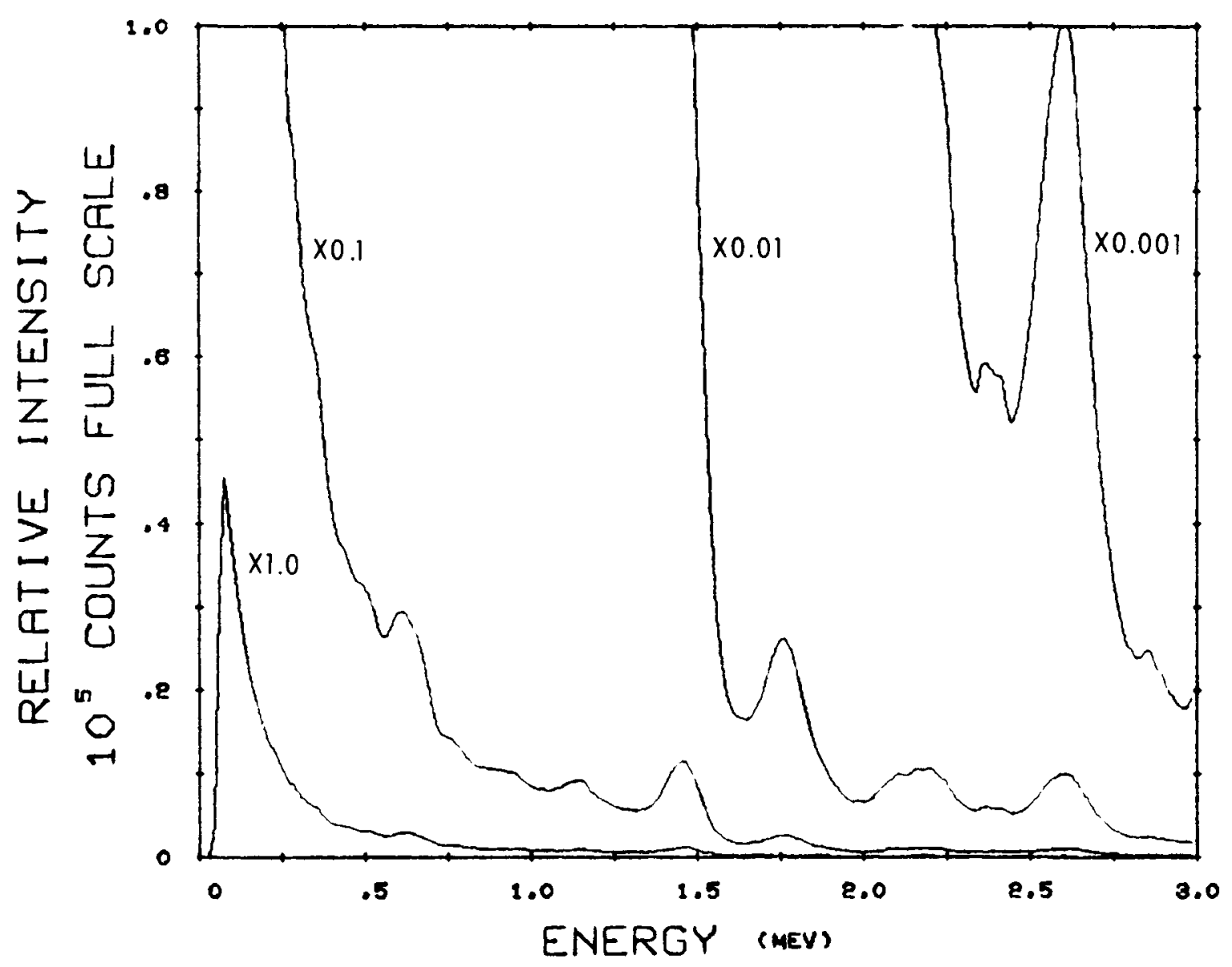

LOCATION: LINE 21 (ENTIRE FLIGHT LINE)

SPECTRUM NO. 718

DATE OT-15-68

LIVE TIME $\quad 4.00$

INTEGRATED CT . 519978

TYPE ACFT TERRAIN BKG.-GND. DEPO. ALTITUDE 300

AIRCRAFT ( $T$ TMS) 


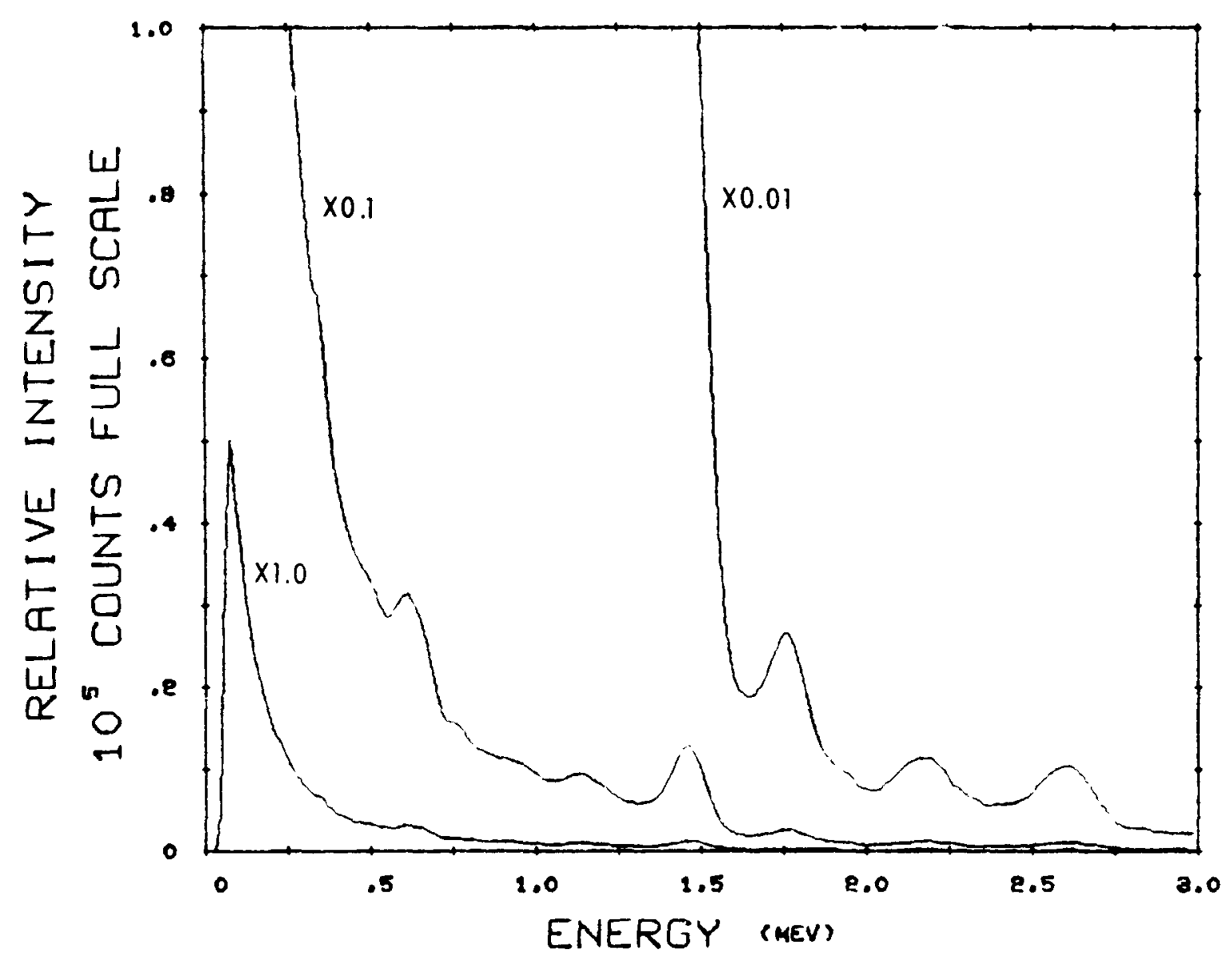

LOCATION: LINE 23 (ENTIRE FLIGHT LINE)

SPECTRUM NO. 719

DATE OP-15-68

LIVE TIME 4.00

INTEGRATED CT. 555050

TYPE ACFT TERRAIN BKG.-GND. DEPO. ALTITUDE 300 AIRCRAFT ( ARMS ) 


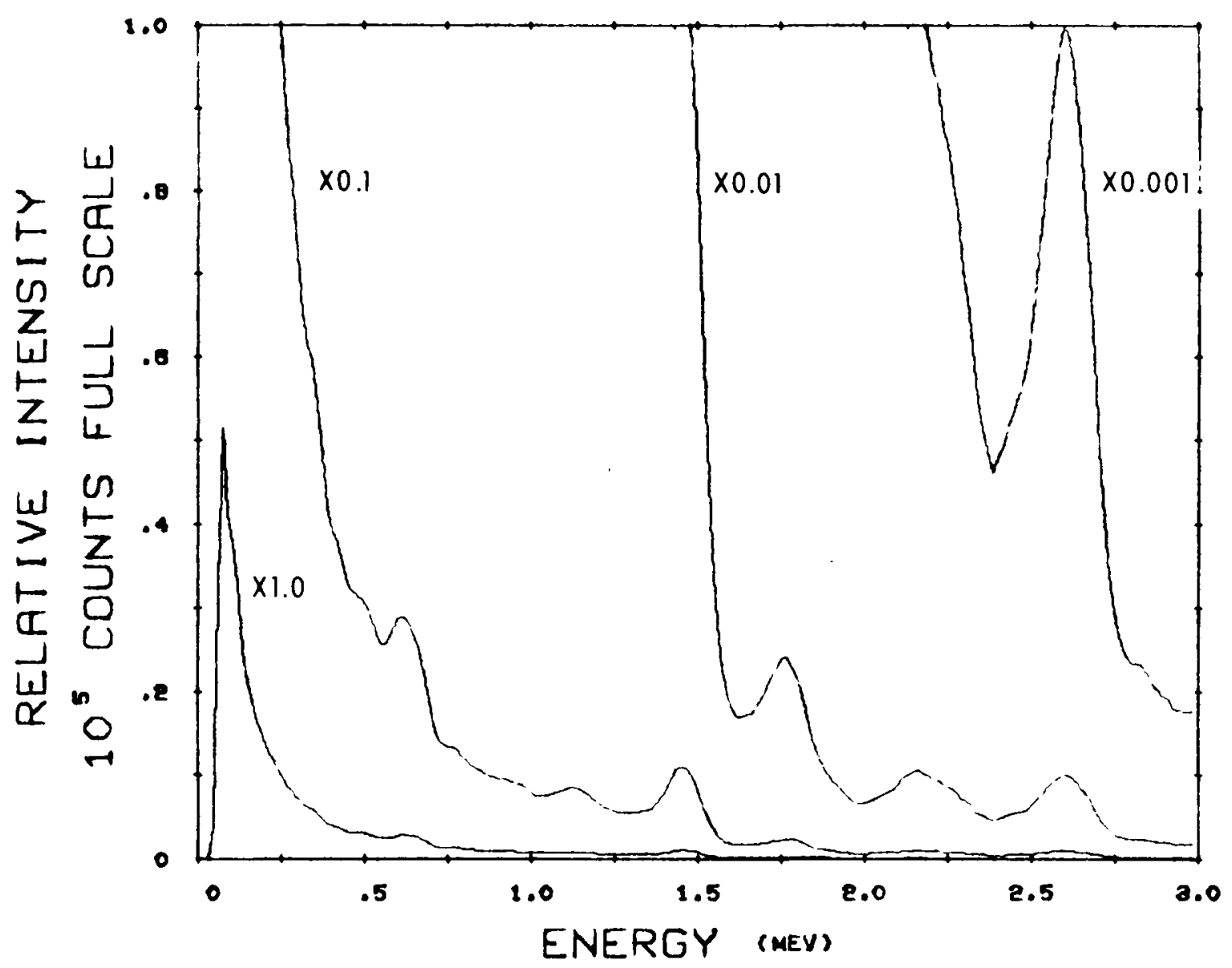

LOCATION: LINE 25 (ENTIRE FLIGHT LINE)

SPECTRUM NO. 720

DATE O7-15-68

LIVE TIME $\quad 4.00$

INTEGRATED CT. $\quad 515339$

TYPE ACFT TERRAIN BKG.-GND. DEPO. ALTITUDE 300

AIRCRAFT (ARMS) 